\title{
Analysis of the Influence of TNCs on the Economy of Developing Countries and Countries with Economies in Transition
}

\author{
Farida Jorubova
}

BA in Economics, International Finance Faculty, Department of World Economy and International Finance, Financial University

\begin{abstract}
Formation and expansion of TNCs, particularly in developing countries and countries with economies in transition, is primarily due to a complex network of international production and localisation activities on promising markets at the expense of foreign direct investments (FDI). These processes every year is increasingly becoming one of the key components of the global economy. Tasks of this paper are to describe the nature and content of the concept of "transnational corporation", to identify critical factors and characteristics of the modern transnational business in developing countries, countries with economies in transition, and to consider the place and role of TNCs in developing countries and countries with economies in transition.

Keywords: TNC; FDI; globalisation; BRICS

JEL Classification: F14, F21, F23

(c) Farida Jorubova, 2020
\end{abstract}

\section{Introduction}

There are many ways for the evaluation of the activities of TNCs - foreign direct investments (FDI), portfolio investment, direct contracts. With their help TNCs form, deepen and expand the system of international production and trade. To assess the extent of the TNCs international integration activities on each of these forms is often quite complicated, especially when it comes to the economy individual countries and sectors.

Currently, the perfect indicator of the TNCs trends development is foreign direct investments (FDI), which serve as the main international exchange of capital instrument. On FDI, there is a good data of systematic statistical material, sufficient to the TNCs participation evaluation in varying countries in international integration and globalisation processes, including their activities in various sectors.

In 2012, the world FDI inflows amounted to $\$ 1351$ billion, to the 2018 FDI inflows rose to $\$ 1430$ billion $^{1}$. Stormy TNCs activity in different

\footnotetext{
${ }^{1}$ UNCTAD. World Investment Report 2018. URL: https://unctad. org/en/PublicationsLibrary/wir2018_overview_ru.pdf (accessed: 20.04.2019).
}

spheres of the world economy has meant that to date the TNCs control over 50 per cent of world production and more than 65 per cent of world trade, thereby forming more than 25 per cent of global GDP.

Russia and Brazil, who are members of BRICS, according to the UN methodology, are related to developing countries. Since the beginning of the $21^{\text {st }}$ century, BRICS states reinforce their positions in the world economy. In 2012 these countries accounted for about 27.1 per cent of world GDP, to 2018 this proportion rose to 32.7 per cent ${ }^{2}$.

However, there are several institutional issues which determine recessive TNCs development in Russia and Brazil. Remains far distance of Russian and Brazil TNCs from the world's largest TNCs, headquartered in developed countries, which resulted in advanced manufacturing technology, financial resources shortage, inefficient management methods, absence of high level international

\footnotetext{
${ }^{2}$ EconomicData.ru. Statistics: Brazil. URL: https://www. economicdata.ru/country.php?menu=america-country \&cu $\mathrm{id}=28 \& \mathrm{cu}$ _ticker $=$ BRA \& country_show $=$ economics (accessed: 20.04.2019).
} 
territorial production diversification, high level of corruption and, in general, closed, and low economy transparency.

This raises the deeper analysis need for both the impact of TNCs on the economies of Russia and Brazil and, in turn, influence the economies of Russia and Brazil on the TNCs activities, which results in the relevance of the chosen research topic.

\section{Literature Review}

The degree of research topic scientific development: the founder of the international production theory, linkages between TNCs and direct investment is considered S. Hymer. In the following years, various aspects of the TNCs activities in international economic relations have made such economists as P. Buckley, J. Dunning, N. Behrman, R. Vernon, R. Grosse, C. Kindleberger, M. Casson, K. Kojima, S. Lall, J. McManus, T. Ozawa, M. Porter, etc.

The TNCs activities in the context of the overall capital transfers problems were characterised in the works of B. Olin, E. Heckscher, K. Iversen, R. Nurkse and other researchers based on which were prepared more specific publications on the TNCs activities, such researchers like E. Penrose, M. Posner, G. Hufbauer, R. Coase.

Problems of TNCs activities in different world regions and countries are covered in the works of such authors as A.S. Belousov, T.J. Belous, V.A. Vinogradov, N.P. Gusakov, R. I. Zimenkov, A. V. Kuznetsov, A. G. Movsesyan, E. P. Ostrovskaya, E.M. Romanova, G.P. Solus, L. N. Fedyakina, E.S. Hesin, Y.I. Yudanov, J. Humphrey, O. Memedovic, J. Sturgeon, and others.

In domestic literature, the TNCs functioning problems in developing countries and their international exchange of capital participation is reflected in the works of I.O. Abramova, O.T. Bogomolov, N.A. Volgina, S.Y. Glazyev, S.V. Zhukov, A.V. Kuznetsov, A.A. Movsesyan, V.A. Oreshkin, G.E. Roshchin, L.L. Fituni, B.A. Heifetz.

There also are studies conducted at UN, UNCTAD, the International Monetary Fund, the World Bank, the Central Bank of Russia and Brazil, Customs statistics of Russia and Brazil, Federal statistical service of Russia and Brazil, normativelegal acts regulating the TNCs activities in Russia and Brazil, international agencies data, press materials.

\section{TNCs: Concept, Criteria for Attribution, Types}

Nowadays, development in the international economy and international trade is increasingly defined by globalisation. Transnational corporations (TNCs) play a significant role in this process. They have several apparent advantages as compared to start-up companies and national enterprises: efficient use of material resources, labour force and timing budget; cost-cutting at the expense of scale economy; technology and capital flow from countries and sectors with higher unit costs to ones with lower unit costs. As a result, more efficient use of available resources and capital assets. According to the Heckscher-Ohlin theory of international trade, countries, and sectors where comparative labour content per unit of output is lower score an advantage [Regional economy, 2017]. Transnational corporations take advantage of the backdrop of the world market due to several reasons ${ }^{3}$ :

The sophistication of market relations - increased competition on the national and international markets; creation of barriers to entry and exit (tariff barriers), increased the homogeneity of market relations; regulatory tightening of corporation' activity and the stakeholders' attention to the results of their activity

Creation and development of global value chains - diffusion of technological innovations, development of crowdfunding, innovative projects outsourcing, high-tech frames

Growth of economic, ecological, and social ties between countries and national economies, hence TNCs become the main trend-watchers of advanced technical, economic, and social projects

Trends in the conglomeration of national enterprises and economies in global value chains. Within this framework, international economic unions assume importance for they aim at liberalising and facilitating entrepreneurship on a cross-border scale. The main organisations are ASEAN, OPEC, SCO, APEC, EU, WTO

Level increase in the TNC's activities in the context of the sustainable development concept - an increase in corporation's transparency, the growth of investments in the 'green business', formali-

${ }^{3}$ Future of working. 7 Advantages and Disadvantages of Multinational Corporations. URL: https://futureofworking.com/7advantages-and-disadvantages-of-multinational-corporations/ (accessed: 20.04.2019). 


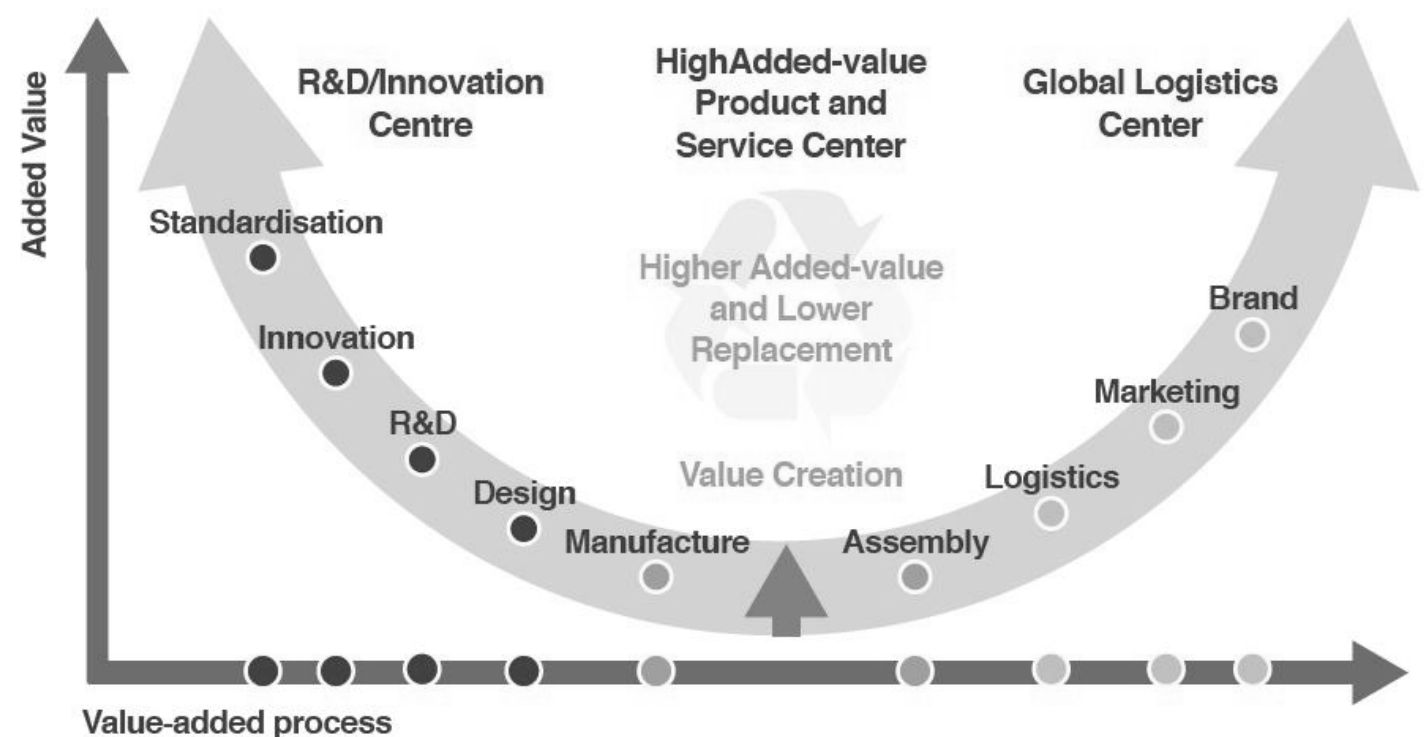

Fig. 1. GVCs circuit - "Smile Face"

Source: URL: https://aftershock.news/?q=node\%2F701564 (accessed: 20.04.2019).

sation of requirements for corporate and social responsibility, ecological consequences, and corporations' integrated reporting, including these entering international commodity, currency and stock exchanges (NASDAQ, FTSE, LSE ${ }^{4}$ ).

The major goal of TNCs' role in the global value chains is the creation of a unified system of the world economy through unifying fragmented enterprises within one general value chain. GVCs as one of the reasons for the business trans-nationalisation will be examined in the next part of the paper from the perspective of value-added groups of companies [Kukushkina, 2016]. Russian and Brazilian markets are attractive to foreign investors. However, internal barriers hamper the creation of the mentioned above chains. Thus, it is relevant to carry out a research on the TNCs on these markets, identify key problems and suggest ways of solution based on perspectives of foreign direct investments and state-private partnership and interaction with small and medium business in these countries [Shimko \& Shimko, 2018].

Value added is the difference between the price of the product at different stages of its production. For instance, if taking the chain 'raw materialssemi-finished goods-end product-goods for resale', each next step adds a fixed interest to the product value. As a result, the value of a semi-finished good

\footnotetext{
${ }^{4}$ Blackwellpublishing. The Multinational Corporation. URL: http://www.blackwellpublishing.com/content/BPL_Images/ Content_store/Sample_Chapter/0631233423/Gooderham_001. pdf (accessed: 20.04.2019).
}

becomes higher than the value of raw material, the value of an end product is higher than the value of a semi-finished good, and the value of a reprocessed and distributed product is accordingly higher than the value of an end product at the enterprise. It takes places due to labour costs (salaries), fuel and energy costs, general expenses of production, general administrative expenses, business expenses, i.e. key elements of the calculation provisions.

Figure 1 shows both backward and forward linkages. That said, the added value is created in both of them. However, export-oriented countries are more likely to undergo risks of global raw materials price fluctuations and more dependent on the import of technologies. Russia is one of the brightest examples of such countries: the budget is shaped owing to oil incomes, and home industry largely depends on the import of the so-called 'high chemistry'. The transition from one development paradigm to another is always challenging for both the country and for the TNCs which represent the country on the world market.

This transition is also known under the name of the Dutch disease. In the middle of the $20^{\text {th }}$ century, the Netherlands has discovered a new gas deposit; however, in 1972, the global energy market forced the country's shift from catching-up development to outstripping development. Consequently, Amsterdam has become one of the cities, leading in the number of start-up companies per capita, i.e. it has shifted from forwarding linkages towards backward linkages [Stragis, 2019]. 


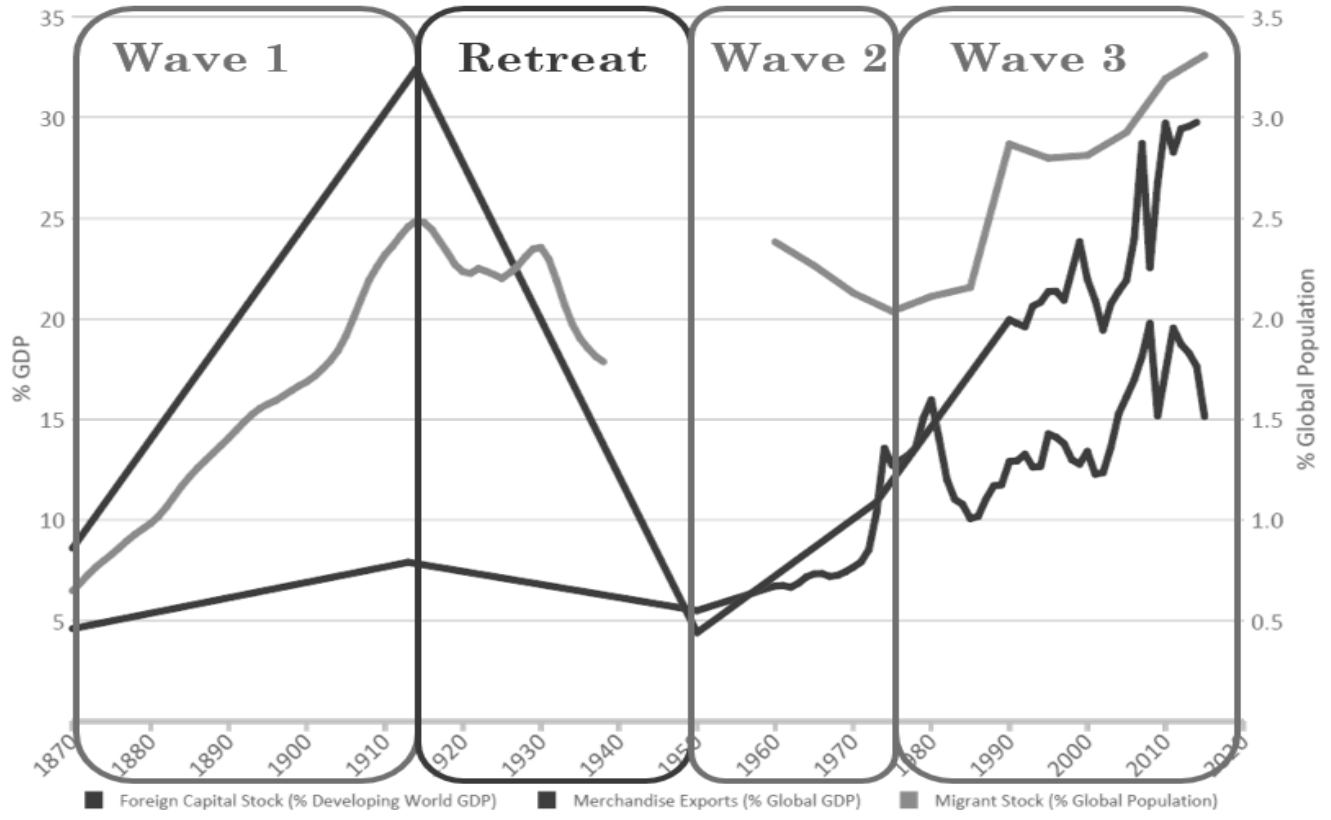

Fig. 2. Three waves of globalisation

Source: AGF Management Limited. Has technology become an enemy of globalisation? URL: https://www.agf.com/ca/en/ insights/market-commentaries/articles/article-has-technology-become-an-enemy-of-globalization.jsp (accessed: 20.04.2019).

The TNCs' activity within the framework of the GVCs may exist in different forms: diversified business (often producing not interrelated goods, e.g. Virgin Group, BIC), segmented and highly segmented business (orientation towards specific products on a specific market for a limited number of consumers, e.g. BI Consult, Rolls-Royce), different forms of cooperation (sophisticated and expensive projects, including the creation of investment pools and financial-industrial groups, for example, NASA and Roscosmos or Space-X and Rocket and Space Corporation Energia). Diversified holding open joint-stock companies as a form of corporate relations dominate in international trade.

The increasing role of TNCs in the world economy is closely related to globalisation. Its nature is manifested in the confluence of material, intellectual, financial, labour (sometimes legal) streams across state borders and continents ${ }^{5}$. Historically, globalisation has been developing in several key stages.

It appeared as a separate notion for the first time in the $19^{\text {th }}$ century in light of growing colonial trade (in the British Empire, France, German Empire, Spain, Portugal [Grechko, 2019]), thus world investment rates represented in Figure 2 are so high.

\footnotetext{
${ }^{5}$ Boston Consulting Group. The power of diversified companies during crises. URL: http://image-src.bcg.com/Images/ BCG_The_Power_of_Diversified_Companies_During_Crises Jan 12 tcm27-106136.pdf (accessed: 20.04.2019).
}

One can notice that the level of investments is even higher than the modern figures. It is possible due to the following mathematical paradox: ensuring high investment rates is easier within small figures than in an extensive system. Let us cite an example: doubling the sales growth from $2 \mathrm{mln}$ roubles to $4 \mathrm{mln}$ roubles is easier and faster than doubling it from $4 \mathrm{mln}$ to $8 \mathrm{mln}$. At the same time, equal two mln sales growth in the shift from 2 to 8 gives a 100 per cent increase, whereas the shift from 100 to 102 gives only a 2 per cent increase, which is 50 times less. Thus, one can see in the figure that the slope of the curve between 1800 and 1860 is significantly greater than the analogous angle between 1960 and 2020, although the analysis period is the same. It will be more noticeable if we are to compose a correlation equation of capital increase at the end of the $19^{\text {st }}$ century. The equation of linear regression shows that the Industrial Revolution, which took place at the end of the $19^{\text {th }}$ century (depending on an industrial sector), greatly encouraged international trade with its peak at the beginning of the World War $\mathrm{I}^{6}$.

Starting in 1920 there was a break-neck fall in production which did not reach the pre-war level in many countries by 1939 (the first year of World

${ }^{6}$ LawBook.online. Definition and characteristics of a transnational Corporation. URL: https://lawbook.online/pravo-torgovli-mejdunarodnoe/ponyatie-priznaki-transnatsionalnoy- 15557. html (accessed: 20.04.2019). 


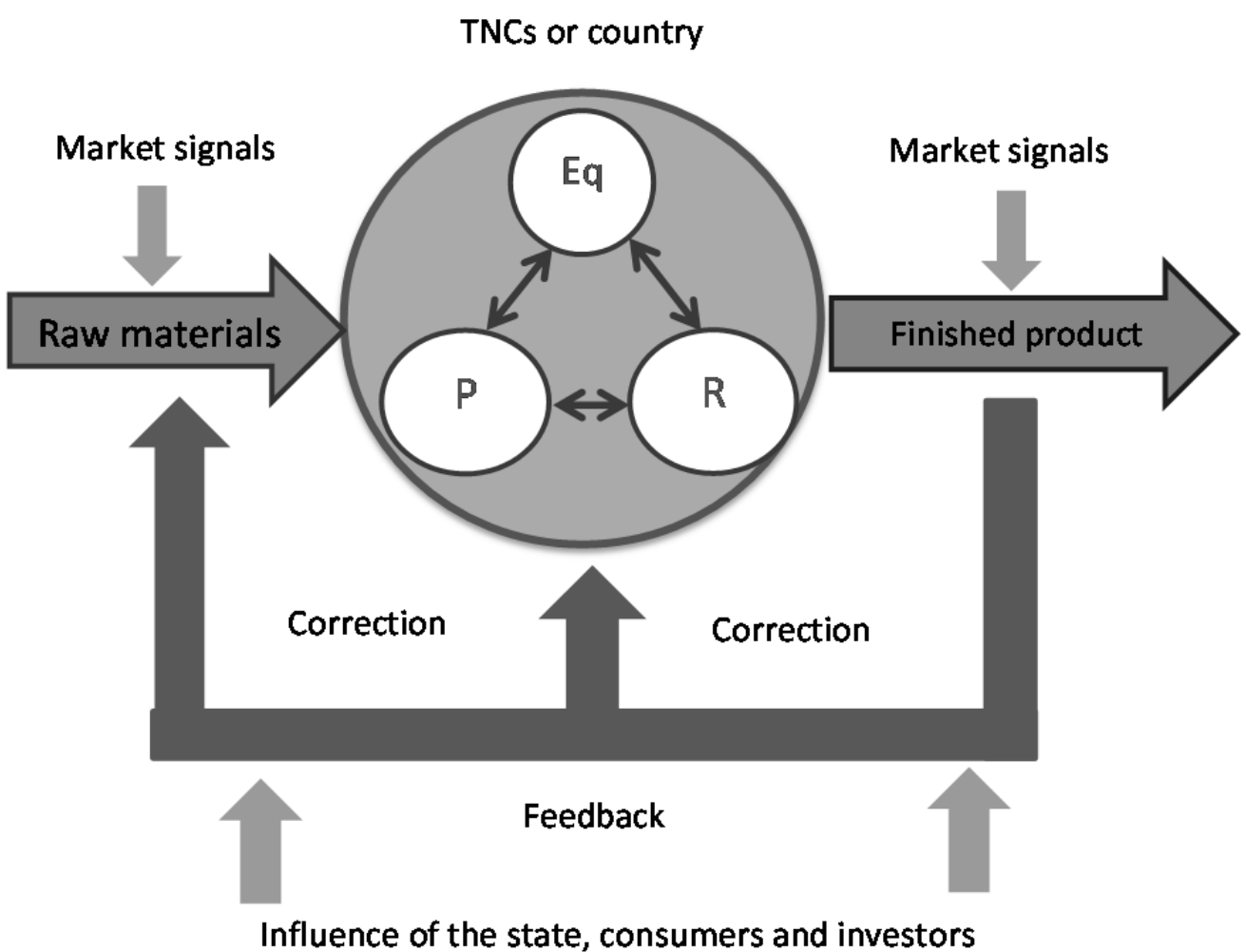

Fig. 3. Country/ TNC development scheme from the system perspective

Source: Compiled by the author.

War II). Further development since 1950 has been showing stable but not booming growth rate worldwide and in the TNCs' sales. It is largely due to the fact that world trade and TNCs as a sample of world trade in miniature are closed systems with communications as a feedback loop. In general terms, it can be developed, as shown in Fig. 3.

This figure allows us to make a statement that there is a direct positive relation between world investments, world GDP and global population. Also, it is natural because it is impossible to ensure investments growth in the context of population decline. It is where the system approach 'Human resources is key' applies, that is population growth increases the number of investors as well as the number of trading operations. Thus, business gains momentum, and so does the world GDP [Kuznetsova \& Podbirala, 2019].

However, this regression model has its limits. Following the UN concept of sustainable development, exponential population growth will constantly reduce the number of available resources per person under set production capacity. Consequently, the technological leap is a must, but it will not happen instantly rather after adequate changes in all the elements of the system (people, capital, resources) are made. Hence, it is possible to predict that any further delay in the world GDP growth and investments and, vice versa, when the population growth reaches its peak, the technological leap will take place signifying a spiral transition to a new level of development according to Kondratiev long economic cycles [Kuznetsova \& Podbirala, 2019].

It is why it is necessary to develop both TNCs and stakeholders associated with them. It will let them make this 'leap'. A similar leap has been subject to implementation in Russia with the help of the national technological initiative (NTI) carried out the agency of strategic initiatives under the President of the Russian Federation ${ }^{7}$. However, efforts to implement the NTI are likely to be a response to external economic sanctions and attempts to reanimate the Russian industry predominantly based on the Soviet legacy. Thus, the attempts to implement nanotechnologies and modernisation have started in the 19170s in the Soviet Union. When analysing the media space of 2018, popular notions of modernisation and nanotechnologies will be barely present in the periodical press or academic papers

\footnotetext{
${ }^{7}$ Agency for strategic initiatives. National technology initiative. URL: https://asi.ru/nti/ (accessed: 20.04.2019).
} 
in comparison to 2007, even though their implementation was planned for a 10-20-year period.

Nowadays, there is a whole variety of opinions on the notion of the TNC in both national and international literature. For example, E. A. Gryaznov argues that TNCs are an advanced organisation type in a multinational corporation which appears at the moment of critical accumulation of industrial, financial and intellectual assets which subsequently are redistributed among two or more countries [Petrova, 2019]. Let us cite an example, where a company possesses enough industrial assets in a particular country, and further territorial expansion is not economically rational. In this case, a multinational corporation (supposedly employing international staff) redistributes its assets by making investments into the building industry or the industrial production first in neighbouring countries and later in other continents ${ }^{8}$. The localisation of production in the People's Republic of China is able to make any enterprise transnational based on technicalities.

As for the legal approach to TNCs appearing in the works of Schmigof and Rakhman [World economy, 2019], TNCs are social, economic, and legal institutions featuring cross-shareholding within different jurisdictions. In such instance, referring a TNC to a competitive country happens at the place of share issue and registration, whereas local specialised registration companies conduct the process of registration. Holdings are a classic example of such a TNC. They are the most widespread organisational forms for both stock companies (Coca Cola) and family firms (IKEA). There are other examples of corporations of a similar legal type: concerns (Volkswagen, Gazprom), consortiums (General Electric, Siemens, Mitsubishi Electric), syndicates (BBC Radio International, Farmers Group Inc.) and trusts (International Nickel Company of Canada - INCO, Unilever [Shimko, 2019]).

The UN, namely, the UNCTAD, gave the classic definition of TNC (although non-official). According to the definition, TNC features the following:

Includes units in two and more countries irrespective of legal forms and business areas

Functions within the framework of decisionmaking system, which allows conducting an agreed

${ }^{8}$ Boston Consulting Group. Tomorrow Never Dies: The Art of Staying on Top. URL: https://www.bcg.com/ru-ru/publications/2015/growth-innovation-tomorrow-never-dies-art-ofstaying-on-top.aspx (accessed: 20.04.2019). policy and carrying out a shared strategy by one directing centre or more

Contains separate units which can have a significant influence on the other's function, in particular, share knowledge, resources, and responsibility with others ${ }^{9}$.

In the 21st century, the UN has corrected the definition by specifying that the minimal 10 per cent threshold for controlling the company's share in the controlled companies' authorised capital. The classic definition of TNC is considered to be relevant for the research and corresponding to the graduation thesis' specificity.

Having analysed Russian and foreign works on international trade and relations between corporate forms of ownership, we can point out several key features in the TNCs' functioning which can be divided into two groups: quantitative and qualitative [Contemporary international, 2019]. Quantitative features can be found and calculated in the corporation's financial, statistical, and administrative reports [Zubenko et al., 2019]. Qualitative features are defined by expert evaluation. The major features characterising the TNCs' activity are provided in Table 1.

According to the Federal Act, there is several criteria which define corporations as TNCs in Russia. Besides, there is a precise definition of a multinational (transnational) corporation. There are special administrative districts, where TNCs' activity is referred to as the place of their localisation (the Isle Russkii, Kaliningrad Oblast). In concordance with the Federal Act 292-FZ as of August 3, 2018, the notion 'personal law of the legal entity' was clarified in paragraph 3 of the article 1202 of the Civil Code of the Russian Federation ${ }^{10}$. It was specified that the personal law of the legal entity is the right of a country where the legal entity was established unless contrary to provisions of applicable law and the Federal International Companies Act 290-FZ as of August 3, 2018 ${ }^{11}$.

${ }^{9} \mathrm{UN}$. Convention agreements. International development strategy for the third United Nations development Decade. URL: https://www.un.org/ru/documents/decl_conv/conventions/dev_strategy_ch3ae.shtml (accessed: 20.04.2019).

${ }^{10}$ The Federal law "On modification of article 1202 of part three of the Civil code of the Russian Federation" of 03.08.2018 No. 292-FZ (last edition). URL: http://www.consultant.ru/document/cons_doc_LAW_304046/(accessed: 20.04.2019).

${ }^{11}$ The Federal law “On international companies” dated 03.08.2018 No. 290-FZ (latest version). URL: http://www. consultant.ru/document/cons_doc_LAW_304052/ (accessed: 20.04.2019). 
Table 1

Criteria for a company to be qualified as a TNC

\section{Criterion}

The value of the criterion

Quantitative features

\begin{tabular}{|c|c|}
\hline Profit margin & More than $\$ 1$ bln \\
\hline Revenue & More than $\$ 10$ bln \\
\hline Number of employees & 10 thousand people \\
\hline Number of nationalities in the staff & More than 2 \\
\hline The number of countries of localisation & At least 2 \\
\hline $\begin{array}{l}\text { Number of subsidiaries, branches, and representative offices } \\
\text { with production capacity }\end{array}$ & At least 3 \\
\hline $\begin{array}{l}\text { The share of foreign capital in the turnover of the } \\
\text { corporation }\end{array}$ & Not less than 25 per cent \\
\hline $\begin{array}{l}\text { Share in the authorised capital of subsidiaries and affiliates } \\
\text { abroad }\end{array}$ & Not less than 10 per cent \\
\hline Information Technology & Not less than 25 per cent \\
\hline \multicolumn{2}{|c|}{ Qualitative features } \\
\hline $\begin{array}{l}\text { Positions in key markets and degree of influence on } \\
\text { consumers }\end{array}$ & Leading \\
\hline Degree of influence on stakeholders & High \\
\hline Decision making system & Centralised \\
\hline Organisational structure of management & Vertically integrated \\
\hline Level of control of regulatory factors & $\begin{array}{l}\text { 1. International Business Standards } \\
\text { Organization (priority) } \\
\text { 2. National business standards }\end{array}$ \\
\hline $\begin{array}{l}\text { Degree of activity restrictions: by national authorities and } \\
\text { international organisations }\end{array}$ & $\begin{array}{l}\text { 1. National - depending on the policy of } \\
\text { protectionism } \\
\text { 2. Supported in the framework of globalisation } \\
\text { and GVCs }\end{array}$ \\
\hline Level of fame in the media & Frequent mention (news) \\
\hline $\begin{array}{l}\text { Number of subscribers in social networks (Twitter, Instagram, } \\
\text { Facebook, etc.) }\end{array}$ & Not less than $1 \mathrm{mln}$ \\
\hline
\end{tabular}

Source: Compiled by the author based on [Nikitochkina \& Makarova, 2014].

In turn, this law defines the legal status of business companies with the status of an international company registered in the Unified State Register of Legal Entities (USRLE) due to a change in personal law in the procedure for replacing a legal address from one jurisdiction to another while maintaining organisational and legal status and corporate structure (re-domiciliation), the rights and responsibilities of shareholders, the characteristics of their activities, and also in connection with the reorganisation or liquidation ${ }^{12}$.

\footnotetext{
${ }^{12}$ The Federal law “On state registration of legal entities and individual entrepreneurs" of 08.08.2001 No. 129-FZ (latest version). URL: http://www.consultant.ru/document/cons_doc LAW_32881/ (accessed: 20.04.2019).
}

Thus, according to the wording of the law, an international company is a foreign legal entity, a commercial, a corporate organisation that has changed its law under the established legislative procedure.

Conditions of obtaining the status of an international company are as follows:

Belonging to a FATF (Financial Action Task Force on Money Laundering) member state or an observer state or a Committee of Experts on the Evaluation of Anti-Money Laundering Measures and the Financing of Terrorism - MONEYVAL member

Conducting business on the territory of several states including Russia 


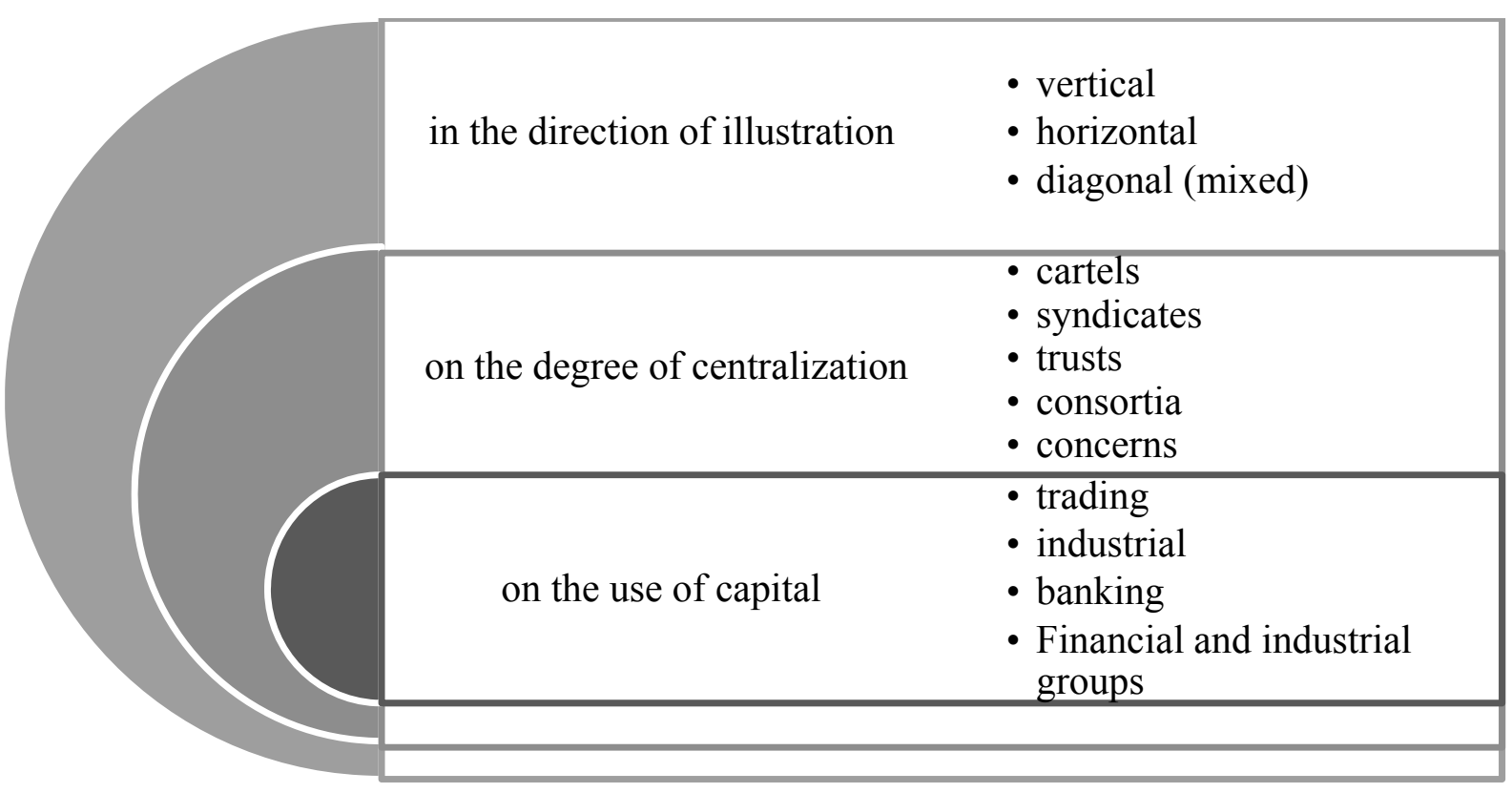

Fig. 4. Types of TNCs (compiled by the author)

Source: Britannica. Multinational corporation. URL: https://www.britannica.com/topic/multinational-corporation (accessed: 20.04.2019).

Investment commitments on the territory of the Russian Federation, with a minimum investment of 50 million roubles for a period of at least six months from the date of state registration of the international company

The abbreviated company name of the international company in Russian should contain the full or abbreviated name of the international company and the abbreviation 'MK', and the abbreviation 'MKPAO' for public joint-stock companies.

The new law also regulates: the results of changes in personal law by foreign legal entities; features of state registration in the status of international companies and the acquisition of this public status by joint-stock companies; regulations on securities and other financial instruments; features of the registration of rights to shares; the procedure for termination of status without changing personal law, or changing personal law when changing jurisdiction.

The features considered, of course, are not strictly regulated; as a rule, the classification of a corporation as a TNC is carried out according to compliance with a larger number of features from the above. Most often, a corporation is a transnational corporation, but it does not necessarily strictly comply with all the chosen criteria. The degree of compliance often depends on the organisational and legal form and the segment of activity. That is, it can be said that a TNC is 'more or less' transnational, depending on its type. For a better understanding of the nature of the types of corporations, let us characterise them in Fig. 4 below.

According to the data from this figure, one can conclude that different types of TNCs react differently to the level of trans-nationalisation and are more oriented towards it [Glosecki, 2017]. For example, vertically integrated corporations are more trans-nationalised than horizontal ones due to the peculiarities of the distribution of raw materials and end products. As for the degree of concentration, for example, trusts are less inclined to form transnational structures, due to the more rigid subordination of corporate units of the controlling company, which may conflict with the need for diversification within the framework of a corporate, divisional structure. In general, TNCs at a high level of their development are inclined to give more freedom to their divisions, while observing a common corporate business policy of development strategy ${ }^{13}$. It is especially evident in new business forms like franchising, outsourcing, outstaffing and the allocation of corporate, investment and venture funds for the implementation of priority and innovative projects. Let us consider the key features of the business trans-nationalisation under current conditions.

\footnotetext{
${ }^{13}$ Boston Consulting Group. Measuring and managing corporate vitality. URL: https://www.bcg.com/ru-ru/publications/2017/strategy-strategic-planning-measuring-managing-
} corporate-vitality.aspx (accessed: 20.04.2019). 


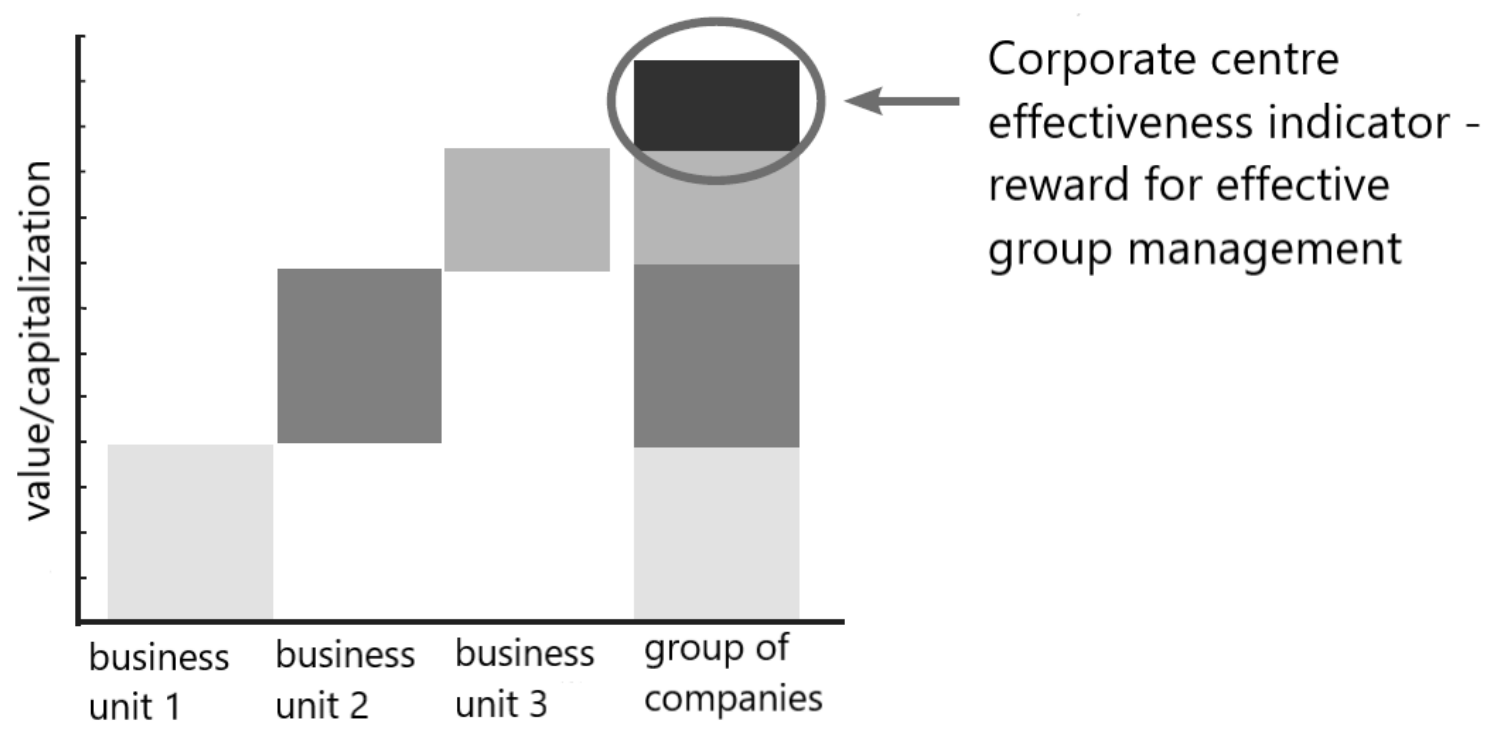

Fig. 5. Synergy effect of the TNC's activity in comparison to other business units' activity

Source: [Leikin, 2017].

\section{Trans-Nationalisation as a New Stage in the Evolution of Emerging Countries}

The effect of global value chains lies in the synergy effect due to which the value of a group of companies becomes greater than each of its divisions separately. Similar processes take place when functions are combined but in the opposite direction. In the global value chain, maintenance costs, functions combined into a unified system, on the contrary, decrease (Fig. 5).

It implies an important conclusion: the efficiency of TNCs depends on whether it brings additional income from the joint implementation of business projects or not. Should the answer be negative, the creation of GVCs, and therefore, the creation of TNCs in general, is not rational. In this regard, the efficiency of the corporation can be conditionally evaluated with Formula 1:

$$
\mathrm{E}=\mathrm{GC}-\mathrm{BU},
$$

where:

E - stands for the effect of the TNC's activity

GC - means the value of the group of companies

$\mathrm{BU}$ - is the total value of the company's business units.

The $\mathrm{E}$ value must be above zero, and it defines the criterion of economic efficiency of the TNC's creation and functionality within the $\mathrm{GVC}^{14}$. Simi-

\footnotetext{
${ }^{14}$ World.Lib. Development and interaction of domestic and international law in the context of globalization. URL: http:// world.lib.ru/o/orlowskij_a/tnk.shtml (accessed: 20.04.2019).
}

larly, the profit of TNC's administrative functions performance is calculated; however, in this case, the result must be below zero.

Let us explain it in detail: TNC products go through several stages from creating a business idea to bringing it to world markets. These are research and development, experimental development, testing (especially important for medical treatments that are subject to many stages of clinical research), pilot production, small batch production, large batch production, market seizure and IPO expansion (as the final stage of recognition of the corporation's success on the market). All the above-listed stages require investments that are significant and riskier at the initial stages (venture capital financing) and less risky at the later stages (mezzanine financing [Krasnostanova, 2014]). The main stages of the investment project life cycle, including entering new markets, are presented in Fig. 6.

Figure 6 shows that the largest share of investment comes at an early stage of the project and its payback depends on how quickly we can bring products to new emerging markets [Gorbatkow et al., 2014]. International relations imply the outsourcing of a significant part of the research functions to small and medium-sized innovative companies that are affiliated with the controlling company. In this case, the greatest effect is achieved with the advanced processing of raw materials and resources. It is confirmed by the following factors: the price of chemical synthesis products (PVC, PET) is significantly higher than the price of petroleum 


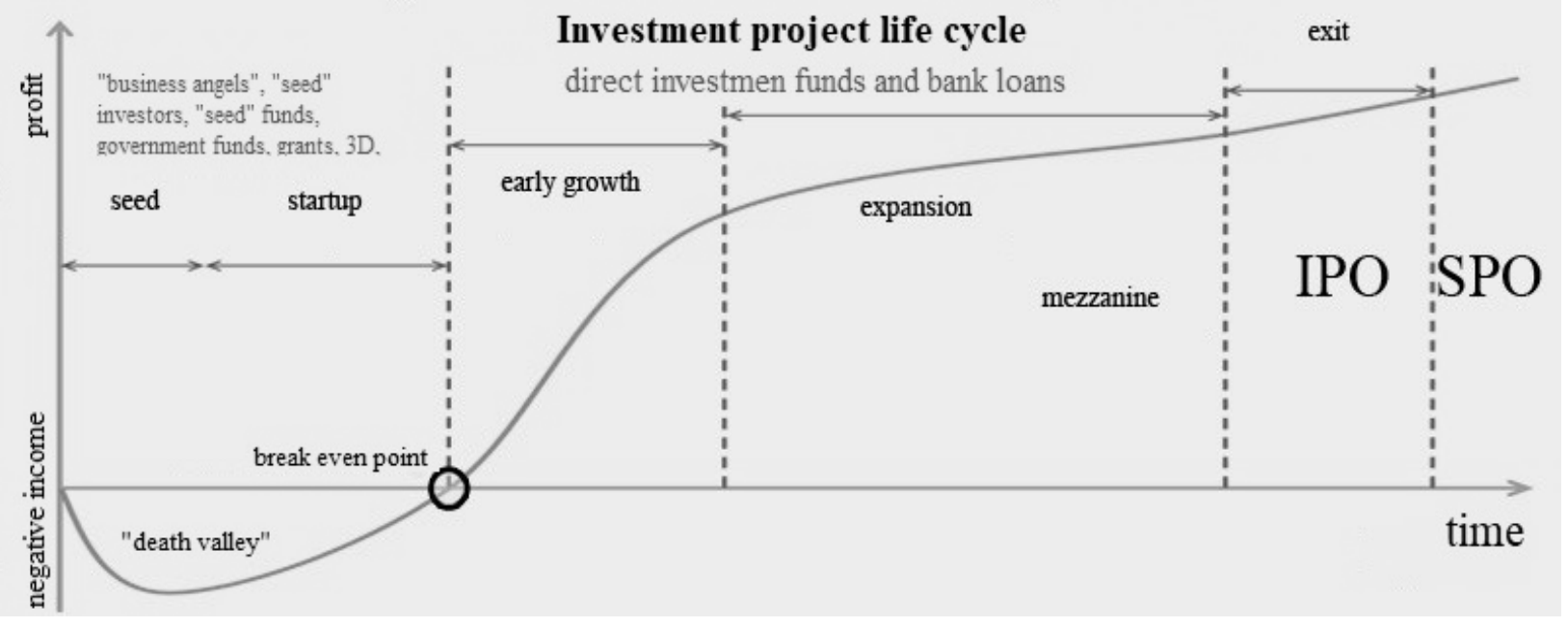

Fig. 6. Investment project life cycle when entering a new market

Source: IT-management, project management, cloud technologies, software development. URL: https://dteplyakov.blogspot. com/2011/11/it.html (accessed: 20.04.2019).

products from which they are produced. Hence, the dependence is obvious. The greater the amount of processing, the higher the economic rent (income derived from value-added). The value of this economic rent determines the level of competition on the relevant market and the number of companies on this market. The conclusion is that the economic rent, created in the value chain, under otherwise equal conditions is higher than the mining rent, derived from the simple extraction of resources (Fig. 7).

As can be seen from Fig. 7, when the flows are ascending, the main part of the value-added is formed outside the country. In contrast, when they are descending, most of the value-added, and, consequently, state revenues, is formed within the country, because foreign corporations localise their production in the country with the best investment attractiveness, credit regime, political and administrative conditions, socio-economic climate, which are components of sustainable development. At the same time, not all the industries are in the same conditions, for example, the presence of foreign oil-producing and refining companies in Russia (not considering their beneficiaries) is minimal (for example, foreign companies in the Russian Federation). And in the pharmaceuticals industry, it is the opposite (Teva, Abbott, Sanofi, etc. [Miloslavskaya, 2014]).

As a rule, countries do not use any particular type of international integration for a long time due to changes in the external economic and foreign policy situations. Therefore, there can simultaneously be present foreign TNCs and the support of national producers in the same country (Russia and Brazil are not an exception [Catmull \& Wallace, 2016). A substantial imbalance in one direction or another is fraught with economic problems for the country; however, there are significant differences between these forms, so the governments have to manoeuvre between the interests of national producers and possible tax revenues from the presence of international TNCs in their countries. A classic example of such a bias is offshore zones (the Seychelles, Cyprus, Belize), where full priority is given to foreign TNCs due to a minimum and zero tax liabilities. An example of bias in the opposite direction can be nationalised economies (North Korea), which does not allow foreign corporations to enter their markets. Therefore, it is necessary to clarify the fundamental differences between these two forms of international integration (Table 2).

GVCs are a direct means of globalisation, that is, the active transfer of technologies, human resources, information from one region to another. This process, like the first corporations, began in the era of colonialism - the active invasion of European countries into the territories of South America, Africa, and Asia. One of the first world corporations is the East India Company (Dutch corporation), which specialised in the import of spices from India and neighbouring countries ${ }^{15}$. Precisely at that moment, both the corporate form of ownership and shares (the rights for the ownership) appeared. Throughout the years of development, corporations had transformed into transnational during the third wave of

${ }^{15}$ Diletant. Honorable East India Company. URL: https://diletant.media/articles/36355214/ (accessed: 20.04.2019). 


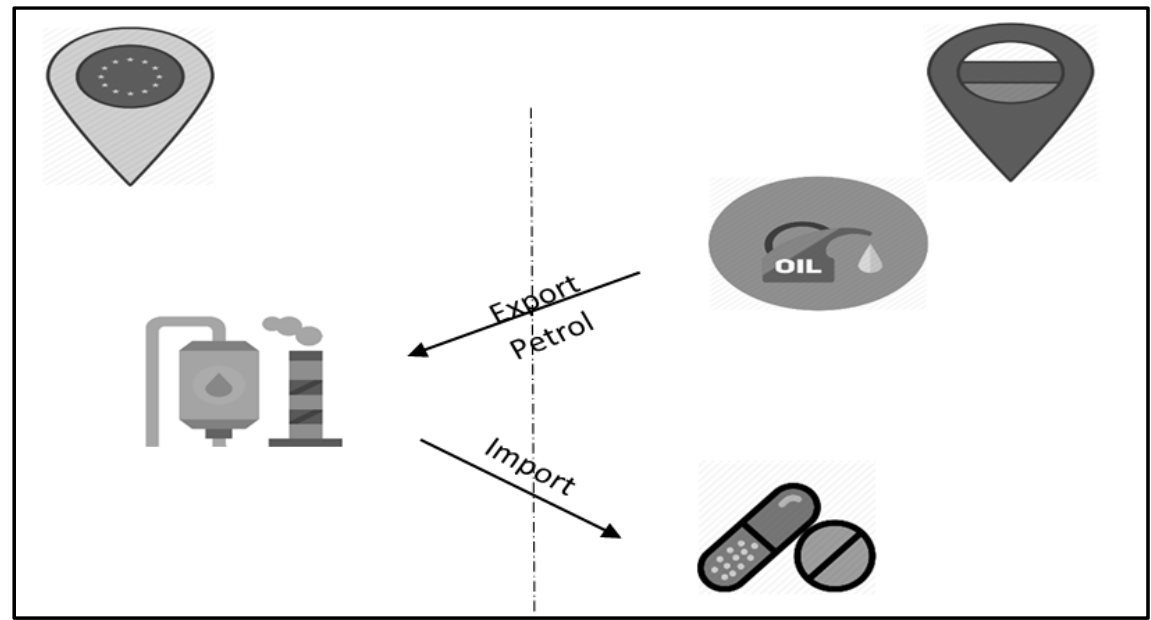

Fig. 7. The process of creating (or forming) value-added in export-import operations

Source: Compiled by the author.

globalisation, when they acquired the main modern features that we know now [Muravyov, 2014].

In general terms, a corporation is a legal entity whose property is distributed among several other legal entities and which manages one or several types of activity ${ }^{16}$. Accordingly, we can say that the concept of a corporation is included in the concept of a legal entity. According to the Civil Code of the Russian Federation, Article 48, 'a legal entity is an organisation that has separate property and is liable for its obligations, can acquire and exercise civil rights on its own behalf and bear civil obligations, be a plaintiff and a defendant in court ${ }^{17}$.

However, 'legal entity' is a broader concept than the concept of a corporation. In turn, the notion of the joint-stock company as the main form of the corporation's activities in the world economy is an even narrower concept. Therefore, it is necessary to differentiate between these terms. In the Russian Federation, a corporation is an entity that has some specific characteristics ${ }^{18}$ :

A legal entity must be registered in the Unified State Register of Legal Entities (Unified State Register) and have TIN, KPP, OGRN codes

\footnotetext{
${ }^{16}$ The Peoples' Friendship University of Russia. Legal regulation of the status of transnational corporations. URL: http:// web-local.rudn.ru/web-local/prep/rj/files.php?f=pf_333e84b2 af05ff43d415e840973d2a21 (accessed: 20.04.2019).

17 "The civil code of the Russian Federation" of 30.11.1994 No. 51-FZ (edition of 03.08.2018) (with changes and additions). URL: http://www.consultant.ru/document/ cons_doc_ LAW_5142 (accessed: 20.04.2019).

${ }^{18}$ OK 028-2012. All-Russian classifier of organizational and legal forms (app. Order Rosstandart of 16.10.2012 No. 505St) (issued 24.10.2018) (together with the "Notes to position OKOPF»). URL: http://www.consultant.ru/document/cons_doc LAW_139192 (accessed: 20.04.2019).
}

'In accordance with the paragraph 1 of the article 65 of the Civil Code of the Russian Federation, corporate legal entities (corporations) are legal entities, where their founders (participants) have the right of participation (membership) in them and form their supreme body. In contrast to corporations, legal entities whose founders do not become their participants and do not acquire membership rights in them are called unitary'

The System of National Accounts 2008 (SNA 2008) provides an extensive definition of a corporation, and the term 'corporation' is used in a wider sense than in a strictly legal ${ }^{19}$. These are all units that:

May gain profits or other financial benefits for their owners

Are recognised by law as legal entities separate from their owners who have limited obligations

Are established to participate in market production and are considered in the SNA as corporations, regardless of how they can characterise themselves and call themselves.

If a corporation is localised in one country and carries out its activity in other countries (including branches, representative offices), then the corporation can be classified as international or, in other words, transnational. TNC is a corporation that uses its capital in carrying out its activities on international markets. In this interpretation, the country of localisation and the availability of production space abroad pale into insignificance, whereas both financial and intellectual capitals

\footnotetext{
${ }^{19} \mathrm{UN}$. System of national accounts 2008. URL: https://unstats. un.org/unsd/nationalaccount/docs/SNA2008Russian.pdf (accessed: 20.04.2019).
} 
Table 2

Comparative characteristics of approaches to the business internationalisation

\begin{tabular}{|c|c|c|}
\hline $\begin{array}{l}\text { Characterised } \\
\text { position }\end{array}$ & TNC localisation & Development of national producers \\
\hline Economic effect & $\begin{array}{l}\text { - an increase in tax revenues } \\
\text { - the transfer of foreign } \\
\text { technologies to the country } \\
\text { of localisation } \\
\text { - training employees in the } \\
\text { sphere of advanced technologies }\end{array}$ & $\begin{array}{l}\text { - the creation of a full value-added a chain and, } \\
\text { therefore, added income within the country } \\
\text { - an increase in competitiveness of national } \\
\text { business } \\
\text { - development of national technologies } \\
\text { and national markets }\end{array}$ \\
\hline Hazard rates & $\begin{array}{l}\text { - access to the socially significant } \\
\text { industries (health care, military- } \\
\text { industrial system, education) }\end{array}$ & $\begin{array}{l}\text { - excessive protectionism can create a } \\
\text { prerequisite for a dishonest competition } \\
\text { (competition of weak producers who will not } \\
\text { strive for improving their businesses) } \\
\text { - Artificial support of non-competitive } \\
\text { enterprises only on the basis of their national } \\
\text { belonging }\end{array}$ \\
\hline Social effect & $\begin{array}{l}\text { - creation of new jobs, charity } \\
\text { initiatives } \\
\text { - environmental protection and } \\
\text { community support }\end{array}$ & $\begin{array}{l}\text { - maintaining employment in mono cities } \\
\text { - creation of the possibility of job retraining } \\
\text { in special economic zones }\end{array}$ \\
\hline Technological trans & $\begin{array}{l}\text { Import of specialists and } \\
\text { equipment with the subsequent } \\
\text { possibility of their employment at } \\
\text { a national enterprise }\end{array}$ & $\begin{array}{l}\text { - the accent placed on technologies included } \\
\text { ones in the priority list, supported by the } \\
\text { government } \\
\text { - the possibility of a farsighted and trend- } \\
\text { watching in line with global trends (transferring } \\
\text { the experience of advanced foreign countries } \\
\text { onto the 'Russian soil', taking into account its } \\
\text { socio-economic peculiarities) }\end{array}$ \\
\hline $\begin{array}{l}\text { The time is given for } \\
\text { the entry }\end{array}$ & $\begin{array}{l}\text { Limited by administrative barriers, } \\
\text { internal economic sanctions, and } \\
\text { customs quotas }\end{array}$ & $\begin{array}{l}\text { Limited by the duration and timing of the } \\
\text { implementation of state programs for the } \\
\text { development of industries and territories }\end{array}$ \\
\hline
\end{tabular}

Source: Compiled by the author based on [Miloslavskaya, 2014].

take the lead in cross-border operations. Stemming from this, in addition to the characteristics that are mandatory for any corporation, some additional features of TNCs can be distinguished [Ponomareva, 2014]:

Involvement of international capital and foreign exchange transactions. That being said, the binding of capital to any state and nationality is not a priority. The priority is only the country of the jurisdiction where active operations involve this capital.

In the era of the development of digital technologies in the economy, and digital marketing in the field of online services, the financial and intellectual nature of business becomes the leader as concerns profits. Therefore, we can see the trend of the gradual transformation of a classic industrial corporation with factories around the world into a virtual corporation. The core of the business is online business operations. To a certain extent, this complicates the process of determining the nationality of TNCs, which is why according to the international law, TNCs pay taxes at the place of localisation of the headquarters. In particular, it leads to the emergence of an offshore zone, where the main income is based on the resources provided by the TNC for its development.

Another important problem of TNCs is the complex, branched, and often closed structure of final beneficiaries. This problem is also indicative of national corporations, but its scale became this large for the first time precisely on the international scene. In this regard, the results of the activities of international commercial organisations are worth mentioning: Transparency International regularly 


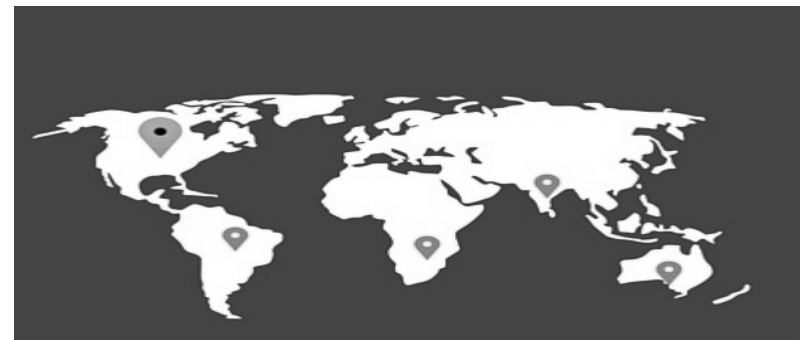

- Multinational companies own a home company and its subsidiaries.

- Multinational Companies have a centralized management system.

- Multinational companies will face a barrier in decision making due to its centralized management system.

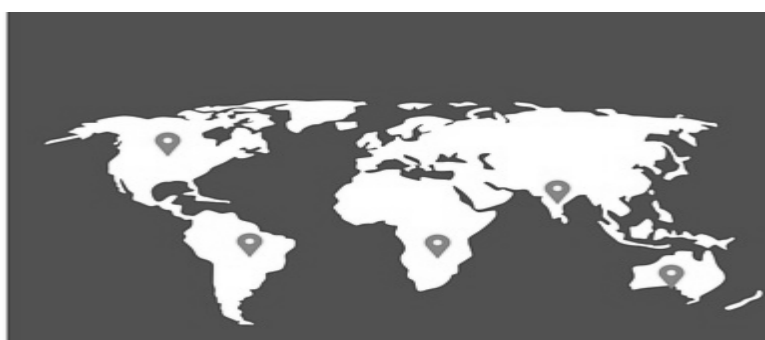

- Transnational companies do not have subsidiaries but just many companies.

- Transnational companies do not have a centralized management system

- Transnational companies are able to gain more interest in the local markets since they maintain their own systems.

Fig. 8. Differences between MNCs and TNCs

Source: Redsearch. Multinational corporations meaning. URL: https://redsearch.org/images/p/multinational_corporations_ meaning (accessed: 20.04.2019).

publishes reports on the transparency level in international corporations ${ }^{20}$.

Some researchers note that working for the benefit of the international community, including international staff is a very distinctive feature of TNCs, as opposed to national companies working for the benefit of a separate state or an individual nation. In this regard, it should be mentioned that TNCs are much closer in adopting the philosophy of sustainable development than individual enterprises or national corporations; hence, TNC is a corporation working for the good of the world. In most cases, TNCs appear under conditions of a critical concentration of capital on the national market, and therefore, in search of a sales market, national corporations switch to other countries' markets and thus, become transnational.

It is interesting to note that in the international legislation (as in the Russian norms) there is no normatively approved definition of TNCs (laws are limited to the definition of 'corporation'). It happens since, unlike national corporations, TNCs

${ }^{20}$ Transparency International. Transparency of corporate reporting. URL: https://transparency.org.ru/research/v-rossii/ prozrachnost-korporativnoy-otchetnosti-transperensi-otsenila-prozrachnost-krupneyshikh-rossiyskikh-kompaniyna-2-6-iz-10.html (accessed: 20.04.2019). can change their location and relatively they can change their national identity [Tekutiev, 2017]. It means that if a country's, for example, the level of taxation does not suit TNCs, international norms allow them to change its jurisdiction. That is why, for the purposes of further research, if this does not create contradictions, we will identify the concepts of a corporation and a TNC (as well as their features). Features of a corporation as a more aggregated concept comply with the ones of TNCs; however, the international business community identifies several specific criteria by which MNCs can be distinguished from TNCs. These differences are presented in Fig. 8.

Another vital feature of TNCs is the presence of developed divisional organisational structures, which is due to their inclinations towards working on the markets of various countries and continents [Fomina, 2016]. For example, if a company from France plans to develop in Hong Kong, sooner or later, it will need to improve its organisational structure (usually linear-functional) into a divisional one (see the Fig. 9).

In addition to this, TNCs are well adapted for organisation matrixes. The experience of the Pixar and Google shows that the opportunities of distributed management in TNCs are higher, which makes it 


\section{The Director of the division $\mathrm{A}$ \\ Director of production in the country A \\ Director of sales in the country A \\ Director of procurement in the country A \\ PR Director in country A \\ CEO \\ The Director of the division $B$ \\ Director of production in the country B \\ Director of sales in the \\ country B \\ Director of procurement in the country B \\ PR Director in country $B$}

Fig. 9. Company’s organisational structure

Source: Compiled by the author based on [Romachkin, 2016].

possible to effectively implement the ideas of "creative management", "offices without superiors" and "brainstorming". At the same time, the risks of TNCs' activities are also higher than natural risks. Apart from organisational risks associated with managing a complex organisational structure, there are some other risks which are very representative of TNCs. These are financial risks associated with changes in the global currency picture, production risks associated with a huge number of suppliers, contractors and customers, personnel risks associated with different levels of education, income, cultural development, administrative risks associated with the different investment climate and conditions of business management, environmental, etc. In the following, we will examine specific examples of TNCs in developed and developing countries ${ }^{21}$.

\section{Place and Role of TNCs in the Economies of Developing Countries and Countries with Economies in Transition}

Currently, there is no single approach to the division of countries into underdeveloped countries, developing and developed ones. There are more common approaches of the UN, World Bank, WTO to ranking countries and territories. Although the current stages of development of TNCs are char-

\footnotetext{
${ }^{21}$ UN. Transnational corporation and export competitiveness. URL: https://www.un.org/ru/development/surveys/docs/investments2002.pdf (accessed: 20.04.2019).
}

acterised by globalisation, and the flow of capital from one area to another, (which in theory should level the gap between countries) and the development of national economies is still uneven. For many reasons, because of the policy of protectionism, many because of the different levels of natural resources (as the main factor of economic growth).

At present, countries are graded by level of development mainly on economic grounds: level of consumption, level of per capita income, potential and real GDP. However, there are no clear boundaries between one and another level. It is largely because the level of development of the country is something more than just its economy. For example, the presence of a large number of natural resources, but the concentration of them in the hands of a narrow stratum of the population does not make the country truly developed. However, the indicators of economic activity will be at a high level. It shows the imperfection of using only economic values, especially averages. In this regard, social and environmental factors are of special importance. That is why currently popular indicators such as the human capital development index, the quality of life index, happiness index, characterising the non-financial aspects of life in the country.

In general, this classification dates back to the era of colonialism, according to which the dominions belonging to the developed countries, the co- 
Table 3

Classification of countries by level of development for 2019 (compiled by the author)

\begin{tabular}{ll}
\hline \multicolumn{1}{c}{ Organisation } & Country \\
\hline United Nations Organization & Developed countries \\
International Monetary Fund & New Zealand, Singapore, Hong Kong SAR (China) \\
World Bank & New Zealand, Singapore, Hong Kong SAR (China) \\
& New Zealand, Singapore, Hong Kong SAR (China) \\
\hline United Nations Organization & Developing countries \\
International Monetary Fund & India, Brazil, Israel \\
World Bank & Russia, Turkey, Armenia \\
& China, Republic of South Africa, Malaysia \\
\hline United Nations Organization & Underdeveloped countries \\
International Monetary Fund & Congo (Dem. Rep), Somalia, Eritrea \\
World Bank & Congo (Dem. Rep), Somalia, Eritrea \\
\hline
\end{tabular}

Source: International Monetary Fund. World Economic Outlook. URL: https://www.imf.org/en/Publications/WEO (accessed: 20.04.2019). The World Bank. World Bank Country and Lending Groups. URL: https://datahelpdesk.worldbank.org/ knowledgebase/articles/906519\#High_income (accessed: 20.04.2019).

lonial countries count as the developing countries, and the countries not involved in either of these classes - belongs to underdeveloped countries. However, we believe that a correct classification in current conditions should be based on the degree of raw material processing in the ascending and descending flows of the global value chain. In this regard, we can say with confidence that economies in underdeveloped countries are based on the use of agriculture (agricultural countries), developing countries of the lowest type, for example - on the use of natural resources, developing countries of the highest type - on the processing of the natural resources, the most developed countries are based on the use of IT technologies. Let us consider the main approaches to the classification of countries, which are presented in Table 3.

The division of countries, according to the level of development, is carried out in different international organisations on a territorial basis as well ${ }^{22}$. It is due, firstly, to the historical features of the activities of these organisations, secondly, the influence degree of the countries in an international organisation and thirdly, the line of activities of

\footnotetext{
${ }^{22}$ Central Intelligence Agency. The world factbook. URL: https://www.cia.gov/library/publications/the-world-factbook/appendix/appendix-b.html (accessed: 20.04.2019).
}

international organisations (whether it is more focused on Asia, Europe or America) ${ }^{23}$. However, regardless of the classification, the level of development as a whole is determined by economic factors: the classification of countries into a group usually affects their investment and credit rating (countries also have credit ratings as companies). The level of development of the country is also determined by the presence of TNCs, by the level of foreign direct investment in the economy, and by the degree of trans-nationalisation of national economies compared to competitors as well as. The main criteria based on which countries belong to a particular group include the following:

Economic: the level of taxation, administrative barriers, the indicator characterising the system of national accounts (GDP per capita, GNP, IRR, national saving etc.), the level of national investment (including direct), the consumer purchasing power, the inflation rate, the availability and accessibility of natural resources, a developed system of the service industry, the unemployment rate and labour market regulation, the level of development of the banking sector and the

\footnotetext{
${ }^{23}$ UN. Standard Country or Area Codes for Statistical Use. URL: https://unstats.un.org/unsd/methodology/m49/ (accessed: 20.04.2019)
} 


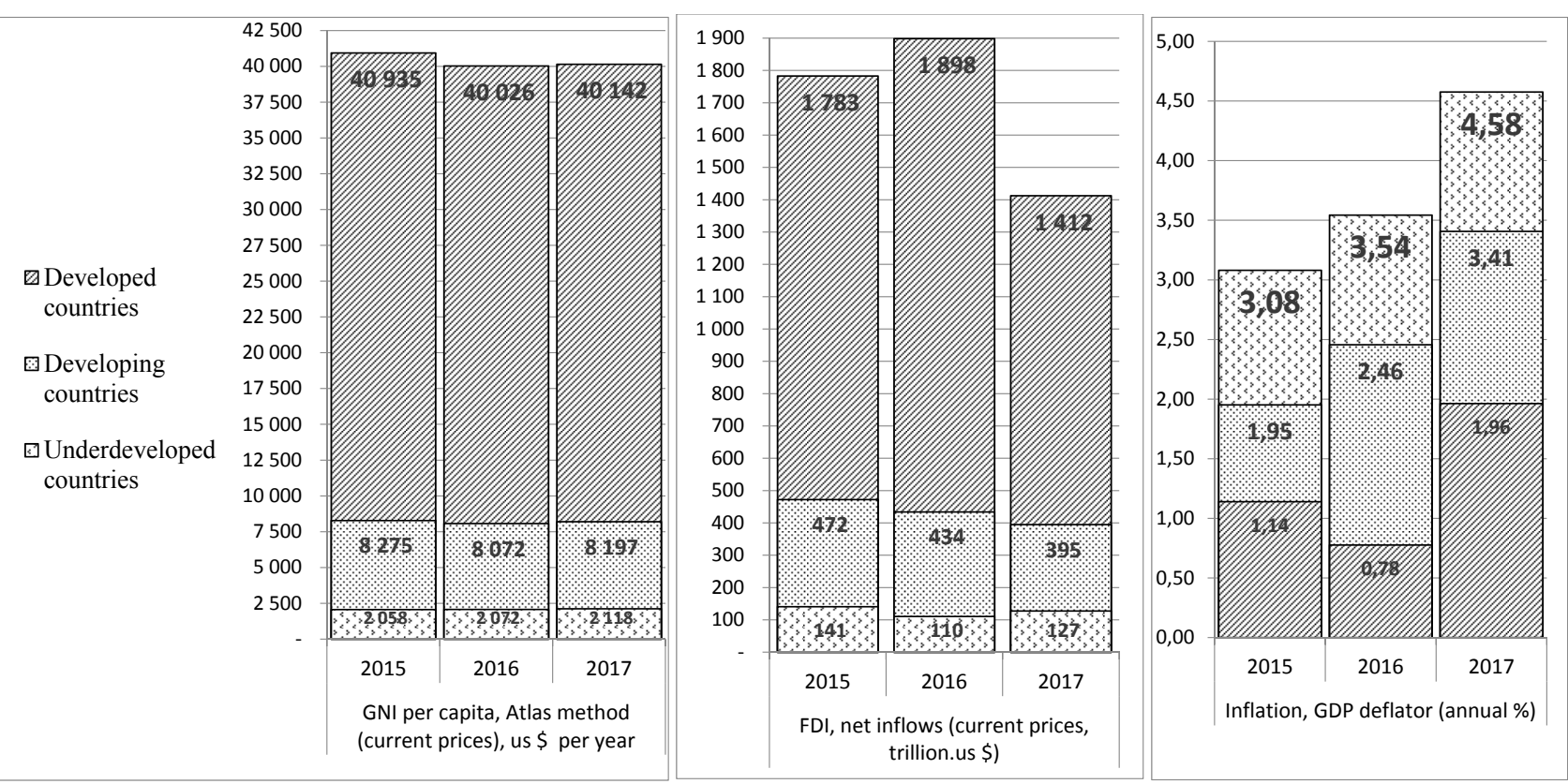

Fig. 10. Comparative characteristics of TNC activity on economic aspects of activity (2015-2017)

Source: Compiled by the author based on The World Bank. DataBank. URL: https://databank.worldbank.org (accessed: 20.04.2019).

accessibility of credit resources, the degree of liberalisation - protectionism (Fig. 10)

Infrastructural: the level of availability of electricity (water), fuel energy, transport accessibility, access to the Internet, logistics and material support

Social: the education system development, the level of democratic freedoms and the degree of openness of the market, health level, level of education, the degree of mandatory execution of the contract (including social), protection of the ecological environment, the development of social institutions (judiciary), the level of business protection. To characterise the level of doing business in the country and therefore classify it as one of the selected groups, we will use the methodology of the World Bank based on which we will conduct an inter-price study using the selected parameters: GDP (current US\$), GNI per capita, Atlas method (current US\$).

The methodology of the World Bank provides the ability to operate with data of both individual countries and entire territorial and territorial-economic complexes to objectively reflect the differences between developed, developing and underdeveloped countries. For this analysis, we selected a group of countries with high income - to characterise developed economies, countries with middle to middle-high income level to characterise the developing countries and countries with low income as a characteristic of underdeveloped countries. This classification is quite objective since it is the level of income that underlies the division of countries and economies.

As can be seen from the above figure, to date, the situation with the level of trans-nationalisation of business and quality of life in the world varies significantly, which certainly contributes to the growth of social tension. Pay attention to the gap in per capita income in developed and underdeveloped countries - it differs by more than 20 times! It is primarily due to the high cost of labour and labour force for the citizens of developed countries. Besides, the development of judicial, administrative and tax systems contribute to increasing investors' confidence in companies from these countries. Needless to say, if the start-up of the "third world" country company has almost no chance to enter the international arena!

The active development of the business of the "Golden billion" creates a situation where 90 per cent of the world's wealth and resources in one way or another are in the hands of 10 per cent of the world's population. Therefore, the business environment in developed countries is such that rich enterprises become richer and poor companies become poorer. So middle-income countries tend to gravitate more towards developed than underdeveloped countries in terms of their performance. Indicators of foreign direct investment in the economy 
Table 4

Comparative characteristics of TNC activity on infrastructure aspects of activity (2014-2018)

\begin{tabular}{lccc}
\hline & \multicolumn{3}{c}{ The time required to start a business (days) } \\
\hline & $\underline{2016}$ & $\underline{2017}$ & $\underline{2018}$ \\
Underdeveloped countries & 32.0 & 28.5 & 26.4 \\
Developing countries & 23.9 & 23.7 & 22.5 \\
Developed countries & 12.1 & 11.5 & 11.0 \\
& & Tax revenues (\% of GDP) & \\
\hline & $\underline{2014}$ & $\underline{2015}$ & $\underline{2016}$ \\
Developed countries & 15.3 & 15.3 & 15.3 \\
Underdeveloped countries & 12.2 & 11.9 & 11.7 \\
Developing countries & 12.0 & 11.7 & 11.5 \\
& Domestic credit provided by the financial sector (\% of GDP) \\
\hline & $\underline{2014}$ & $\underline{2015}$ & $\underline{2016}$ \\
Developed countries & 203.9 & 199.5 & 206.0 \\
Developing countries & 120.4 & 143.8 & 158.7 \\
Underdeveloped countries & 60.5 & 63.0 & 66.6 \\
\hline
\end{tabular}

Source: Compiled by the author based on The World Bank. DataBank. URL: https://databank.worldbank.org (accessed: 20.04.2019).

can illustrate this. You can see that the difference between developing (transitional) countries and underdeveloped is more than 6 times, and the gap with developed countries is about 2.5-3 times.

A similar situation is observed with inflation indicators but in the opposite direction. One of the main indicators of a developed economy is a consistently low level of inflation - for developed countries it is up to 2 per cent yearly. For underdeveloped countries it is usually more than 4 per cent, and since the data are average for a group of low-income countries, they do not reflect that in some African countries inflation can be even more than 20-30 per cent, which is considered unsatisfactory for the economy. In general, developing countries seek to give TNCs as much access to national resources and finance as possible, in exchange for advanced technologies, when, in developed countries, such technologies already exist, and corporations compete at a higher level than simply for natural resources.

Such a gap is observed not only in the terms under consideration but also in other indicators of the economic sphere of activity. In particular, the volume of GDP in real and value terms in developed countries is also much higher: like the total number of enterprises, total income, value-added in the global value chain, etc. Let us consider the comparative characteristics of infrastructure and social indicators, which are presented in Tables 4 and 5.

As can be seen from the table, the conditions for starting and doing a business start-up in developed countries is about 2 times better than in the rest.

This is due to the duration of licensing procedures, the number of necessary documents and the level of digitisation of state and municipal government. It is believed that the best condition for starting a business provides Estonia and Iceland, where your official business can be started in less than a week. The General trend is that the less developed the economy, the longer the time needed to open a business. It is mostly due to the level of corruption while making such decisions. It is believed that the Scandinavian countries are the countries with the lowest level of corruption; Russia is still in the lower half of the list, which does not allow attracting serious investors with serious intentions ${ }^{24}$.

In turn, tax policy in developed countries shows the opposite trend: countries with developed economies have more stringent tax legislation, and the

\footnotetext{
${ }^{24}$ Transparency International. Corruption Perceptions Index 2018. URL: https://www.transparency.org/cpi2018 (accessed: 20.04.2019)
} 
level of the tax burden is higher than in other countries. One of the most illustrative examples is the tax system of the Scandinavian countries and the United States, where individuals can give up to 40-50 per cent of their income, and legal body up to 70 per cent for tax payments. This system is considered to be more effective, as by means of active tax payments, the speed of money supply turnover increases, which in turn leads to the increased funding for citizens and businesses.

In turn, high velocity of circulation of finance and as a result, the high rate of properties turnover leads to the possibility of improving the ability of credit resources and, indeed, if in your business the rate of money turnover is high, you have more opportunities to take the borrowed funds and as a consequence, a longer shoulder the financial leverage.

For the economy, the developed countries, of course, are above the rest. Still, there is one interesting paradox that considering such indicators as the population, the birth rate, the average number of children in the family, less developed countries are above the developed ones. It is surprising that having so many people cannot convert quantity into quality. Therefore, describing the social indicators, it should be noted that although the expected lifespan in developed countries (more than 80 years) is significantly ahead of underdeveloped countries (about 50 years), they compensate for this lack of high fertility. However, mortality is also (as a result of the weak development of medicine) is high. In contrast, the total population attributable to underdeveloped countries is much lower (hence the problems of migration crises, social revolutions and conflicts that occur in these countries) (Table 5).

Social indicator of the corporation and the economy is the basis for determining the level of human capital. By human capital we mean: first, a set of knowledge, skills and abilities of employees of the corporation, and secondly, the existing human potential - a potential opportunity to improve their hard skills and soft skills, and thirdly, the interconnectedness and interdependence of the human environment with the technical and economic environment, providing an opportunity to improve the quality of key indicators of the corporation.

There are several ways to measure the level of human capital: the simplest is to calculate the additional economic effect that employees bring to the corporation because of the use of human capital by 100 per cent. Another way is to consider human capital through the social aspects of the activity, all other things being equal. It is believed that employees with higher motivation, better health, greater interest in their work will invest their human resources more effectively and improve the quality of management in the enterprise.

One of the main indicators of human capital is life expectancy and, directly related to it, the duration of active working age. These indicators interact with the pension systems of the state and implemented private and public programs for persons of pre-retirement and retirement age, for example: "Moscow longevity" - a program aimed at creating a start-up among pensioners and teaching them the basics of entrepreneurship. Therefore, in developed countries, life expectancy during the period when an employee can generate income for his Corporation and his state is consistently higher on average. Many corporations implement the approach when after retirement age employees do not leave the company, and occupy the positions of business consultants, implement their considerable experience.

It is representative that life expectancy in such developed countries as Japan, Norway, Switzerland is on average higher (more than 80 years) than in countries with economies in transition (Russia, Brazil) on average more than 70 years and much higher than in underdeveloped countries (in some poorest countries 40 years is already considered the old age - Somalia, Eritrea, Western Sahara).

Life expectancy indicators are directly related to the birth rate, and this is natural because the economies with low income and low living standards are trying to compensate for their lag due to the high birth rate, but at the same time due to the underdevelopment of medicine, there is a high mortality rate (including child mortality). In developed countries, having 1-2 children is considered the norm, as the economic support of the state and parents and medicine can guarantee their well-being and quality of life. The economic doctrine of developed countries provides that the state, and sometimes corporations, assume the main burden of care about families when, as in underdeveloped countries, children become a pillar of family well-being - when the state is not in a position to do so.

For the above reasons, there are differences in social indicators between developed and underdeveloped countries. 
Table 5

Comparative characteristics of TNC activity on social aspects of activity (2014-2017)

\begin{tabular}{lccc}
\hline & \multicolumn{4}{c}{ Life expectancy at birth, total years } & \\
\hline & 2014 & $\underline{2015}$ & $\underline{2016}$ \\
Developed countries & 80.4 & 80.3 & 80.4 \\
Developing countries & 74.9 & 75.1 & 75.3 \\
Underdeveloped countries & 67.4 & 67.6 & 67.9 \\
& Urban population growth (annual percentage) \\
\hline & $\underline{2015}$ & $\underline{2016}$ & $\underline{2017}$ \\
Underdeveloped countries & 2.6 & 2.6 & 2.6 \\
Developing countries & 2.2 & 2.1 & 2.1 \\
Developed countries & 0.8 & 0.8 & 0.8 \\
& Childbearing rate, total (number of births per woman) \\
\hline & $\underline{2014}$ & $\underline{2015}$ & $\underline{2016}$ \\
Underdeveloped countries & 2.8 & 2.7 & 2.7 \\
Developing countries & 1.8 & 1.8 & 1.8 \\
Developed countries & 1.7 & 1.7 & 1.7 \\
\hline
\end{tabular}

Source: Compiled by the author based on The World Bank. DataBank. URL: https://databank.worldbank.org (accessed: 20.04.2019).

Also, it should be noted that developed, developing and underdeveloped countries also differ in the number of registered corporations, as well as small and medium-sized businesses. For developed countries, the norm is the share of small and medium-sized businesses (SMEs) to 70-80 per cent of GDP. Let us compare this figure with the Russian economy, and we will see that the share of state monopolies is, on the contrary, up to 80 per cent in the national budget. The same is true for the number of registered legal entities. In the US, which is the largest economy in the world, only legal entities registered more than half a million corporate property standards, not to mention small non-corporate organisations. These statistics are related directly to the economic, infrastructure, and even social aspects, as American pensioners with a lot of free time and money often open their small business, which also makes its contribution to the national economy.

Thus, we see that all three groups of indicators are related to each other and determine the logic of the economy of TNCs in developed countries. Unfortunately, the process of merging national economies and levelling the quality and standard of living in different countries is extremely slow. Therefore, we hope that our proposal, dedicated to the growth of trans-nationalisation in the markets of Brazil and Russia, will help to increase not only economic but also social efficiency of the business in the regions under consideration.

One of the most striking examples illustrating the concept of the relationship of these indicators is the experience of Siemens (production of electronics and railway transport). In early 2018, Siemens offered the French locomotive manufacturer Alcon mutually beneficial cooperation on the mutual purchase of shares, that is, the German company buys shares of the French, and the French, in turn, buys the German shares. It would make it possible to create the largest European railway Alliance and take a privileged market share, with the corresponding creation of jobs, tax increases, high value-added and other benefits for the infrastructure, economic and social sphere.

However, the European Antimonopoly Agency refused the possibility of such a transaction, arguing that it would create a restriction for the largest Chinese manufacturer of railway transport. Note that both European companies protect the rights of 
the European Union, but the requirement of Antimonopoly legislation is higher than the economic interests of the whole region. In the practice of a country with developed corporate legislation, many cases can be found where even positive prospects for the localisation of TNCs have been limited by the interests of local communities.

In American practice, one of the clearest examples are reservations - special economic territories in which the indigenous peoples of America (Navajo, etc.) live, where the activities of companies not owned by Navajo are prohibited. Moreover, even if in the surrounding area this activity is not permitted, for the Navajo Indian company, this activity will be allowed (for example, a gambling establishment (casino) in reservations).

In Russian practise, such restrictions have been developed in the form of external economic sanctions with the EU and the US, as a result of which companies that are not localised on the territory of the Russian Federation have received a ban on the import of their goods from abroad. It was especially true of engineering (equipment for oil refining, chemical industry, etc.), the military-industrial complex and food industry. These restrictions are largely related to the level of imports in the national markets of the countries concerned. In Russia, the share of imported machinery is $90-95$ per cent, chemical industry 70-80 per cent, pharmaceutical industry 60-70 per cent, food about 50 per cent. That is why restrictive measures "hurt the most" in these industries.

After analysing the presented figures, you can see the differences between developed, developing and underdeveloped countries, this is due, firstly, to the varying degree of involvement in the global value chain, secondly, the level of protectionism, and thirdly, the development of national business. However, it should be noted that for the purposes of this analysis, the approved data for the appropriate groups of countries were used. The Atlas conversion method was used to eliminate the side effects of the exchange rate, especially for the period of 3 years. The essence of this method consists, firstly, in the use of the average, not the moment exchange rate (for the previous 2 years), and secondly, the adjustment of the exchange rate at the level of inflation, taking into account its difference with the inflation of the big 5 countries (G-5: France, Germany, UK, Japan, USA).

To account the impact of inflation on economic parameters, we used the GDP deflator. It is the ratio between nominal and real GDP. As you know, positive inflation reduces real GDP in relation to nominal GDP. Similarly, inflation affects the exchange rate: positive inflation reduces the real exchange value of money. Based on this, the conversion rate of the Atlas can be represented as a Formula $2^{25}$ :

$$
C R a=\frac{E x}{I-I G 5}
$$

where:

$C R a-$ a conversion rate of the Atlas

$E x$ - average exchange rate for 2 years

$I$ - inflation rate in the country I selected

IG5 - inflation rate in the G-5 countries.

As a rule, the conversion rate is used when the exchange rate is weak or extremely subject to changes in relation to the world's leading currencies (euros, dollars, etc.). In turn, the GDP deflator is calculated by Formula 3:26

$$
Q=\frac{\mathrm{GDPn}}{\mathrm{GDPr}}
$$

where:

$$
\text { Q- deflator index; }
$$$$
\text { GDPn - nominal GDP; }
$$$$
\text { GDPr - real GDP. }
$$

Let us consider the key differences between the business environment of TNCs in developed and underdeveloped countries. We deliberately do not consider developing countries, as they are close to developed countries in terms of their conditions. The principal difference between the business environment in developed and underdeveloped countries is the degree of influence of TNCs on the national economy and national business Table 6 .

No matter what country we consider, any company carries out its activities on the stability curve, and the risk curve characterises the level of internal and external threats to the company. At the seed stage, the risks are maximised as is the maximum possible initial investment. In the next stages of early growth and expansion, risks gradually reduce

\footnotetext{
${ }^{25}$ The World Bank. World Bank Atlas method. URL: https://web. archive.org/web/20160303202552/http://econ.worldbank.org/ WBSITE/EXTERNAL/DATASTATISTICS/0,, contentMDK:20452 009 pagePK:64133150 piPK:64133175 theSitePK:239419,00. html (accessed: 20.04.2019).

${ }^{26}$ The World Bank. World Bank Atlas method. URL: https://web. archive.org/web/20160303202552/http://econ.worldbank.org/ WBSITE/EXTERNAL/DATASTATISTICS/0,, contentMDK:20452 009 pagePK:64133150 piPK:64133175 theSitePK:239419,00. html (accessed: 20.04.2019).
} 
Table 6

The key differences developed countries and underdeveloped countries by sector

\begin{tabular}{lll}
\multicolumn{1}{c}{ Area (aspects) } & \multicolumn{1}{c}{ Developed countries } & \multicolumn{1}{c}{ Underdeveloped countries } \\
\hline $\begin{array}{l}\text { Level of access and barriers to } \\
\text { entry the market }\end{array}$ & Full access to the national market & $\begin{array}{l}\text { The dominant "eagles" TNCs in the } \\
\text { economy }\end{array}$ \\
$\begin{array}{ll}\text { The banking-credit sector } \\
\text { Tax sphere }\end{array}$ & Low cost of credit & Low-interest rates on loans for \\
High level of the tax burden & TNCs \\
$\begin{array}{l}\text { Availability of natural and } \\
\text { other resources }\end{array}$ & $\begin{array}{l}\text { Full and free access to fuel and energy } \\
\text { resources }\end{array}$ & $\begin{array}{l}\text { Full access and even capture } \\
\text { of local natural resources }\end{array}$ \\
$\begin{array}{l}\text { Sphere } \\
\text { of national accounts }\end{array}$ & High level of administrative regulation & $\begin{array}{l}\text { The high degree of lobbying } \\
\text { in national legislatures }\end{array}$ \\
The infrastructure sector & Lack of dominance in GDP (most of the & $\begin{array}{l}\text { System-forming role of TNCs } \\
\text { in the formation of national GDP }\end{array}$ \\
\hline
\end{tabular}

Source: Compiled by the author.

to a minimum level and then begin to grow again, increasing to a medium-high level. At the mezzanine and IPO stages, the opportunities for further development are due to the company's exit from the stability zone and its transition to a new level, within which the secondary public offering stage is possible, as well as an additional issue of shares and their issue from the lender. In Fig. 11, we present the general dynamics of the level of development and risks of TNCs in the process of investment risk.

You can see from this figure that countries and TNCs are essentially the 'black boxes' of the economy at the entrance, which has raw materials, and the output of finished products. Since the systems under consideration are fundamentally open, their mandatory element is the accounting of market signals to the input and output flows, as well as the construction of the inverse relationship circuit with subsequent corrective action. Any system consists of many elements, for the considered, the main subsystems are labour (people-staff), material (equipment, transport, and buildings), resources (raw materials, semi-finished products, intellectual property, etc.).

The key conclusion and idea of this figure is as follows: revolutionary (abrupt growth), that is, an abrupt (instantaneous) transition to a new level of development is fundamentally impossible without a critical accumulation of innovation and qualifica- tion level in each of the systems, and not only in one of them. Therefore, it is not possible to talk about the improvement of human capital or a financial Corporation in isolation from its production and technological and organisational and managerial level, the potential of which must first be measured (evaluated) before any process of innovation.

All these processes that determine the differences in developed, developing, and underdeveloped countries are caused by processes of transnationalisation. Trans-nationalisation is a flow of capital from regions and companies where they are present in excessive quantities in countries and companies where there is a lack of various forms of capital. This process allows more efficient use of existing factors of production. There are the following types of trans-nationalisation:

Corporate - represents an increase in the role of TNCs in the international economy

Economic - represents an increase in the role of TNCs in the economic and international activities of countries and regions. In this consideration, economic trans-nationalisation appears to be a more mature stage in the internationalisation and development of the global value chain.

There are the following theories of business trans-nationalisation; most of them are aimed at studying foreign direct investment (FDI) in the economy. It is believed that a large part of FDI is 


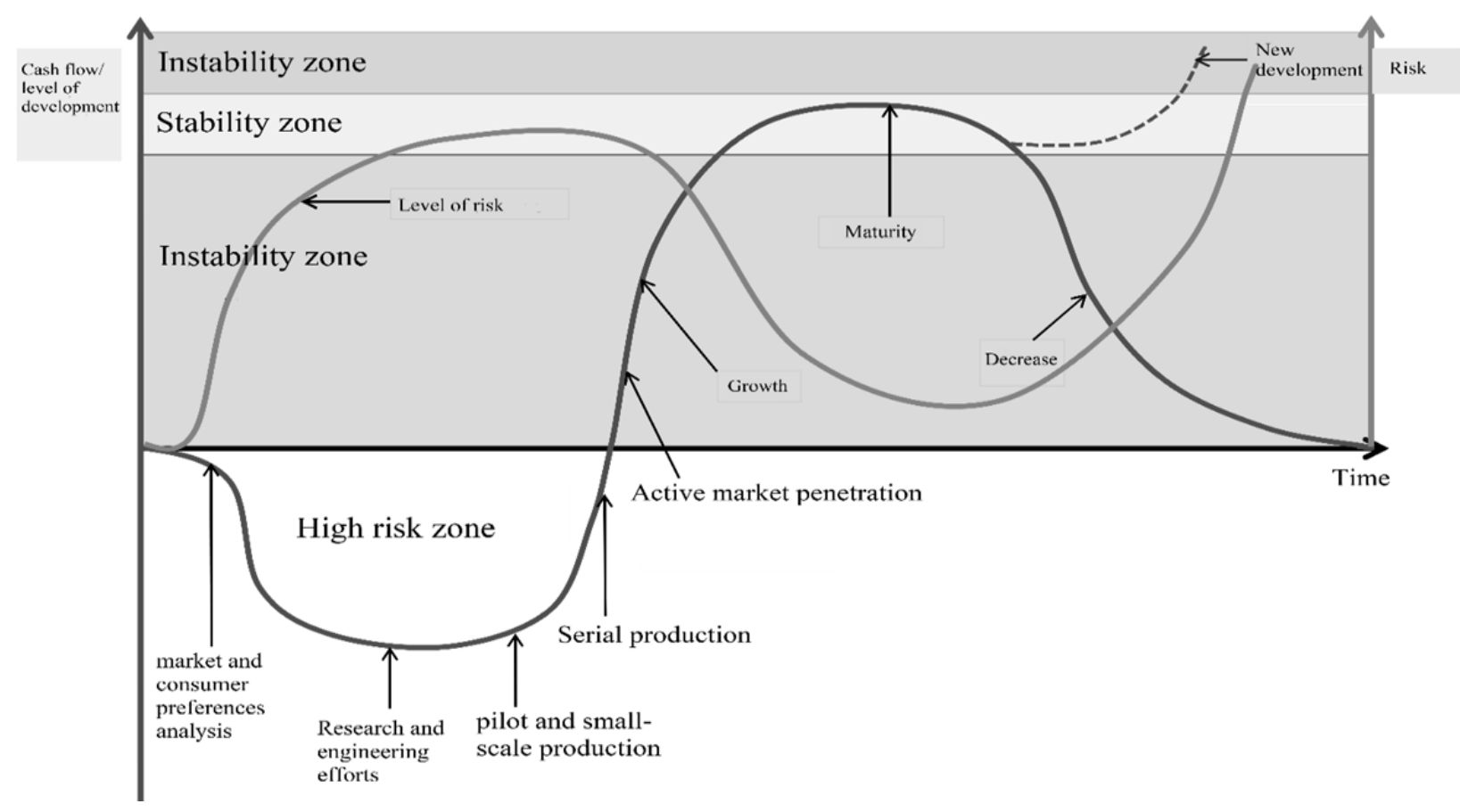

Fig. 11. General dynamics of development and risks of TNCs in the process of investment risk

Source: Compiled by the author.

either corporate (private) or unitary (state-owned) TNCs. Such theories first emerged in the 50s and $60 \mathrm{~s}$ of the $20^{\text {th }}$ century and sought to explain the abrupt increase in FDI and the share of TNCs in world GDP. The development of scientific schools of trans-nationalisation by the end of the $20^{\text {th }}$ century led to the development of several scientific schools (theories): 1979]

J. Dunning theory (electrical theory) [Dunning,

S. Hymer and Ch.P. Kindleberger theory (transnational companies and imperfect competition ${ }^{27}$

R. Vernon theory (life cycle of TNCs) [Vernon, 1966]

H. Кojima и Т. Ozawa theory (flying geese paradigm $)^{28}$

J. Johansson theory (internationalisation theory $)^{29}$.

Most of the theories are based on the analysis of factual material concerning the activities of TNCs in the world from the 1950s to the present. Given the fact that in developing countries, the share of

\footnotetext{
${ }^{27}$ Massachusetts Institute of Technology. Essays in the theory of international capital movements. URL: https://dspace.mit. edu/handle /1721.1/12132\#files-area (accessed: 20.04.2019).

${ }^{28}$ Infeconomy. Paradigm of 'flying geese'. URL: http://www.infeconomy.ru/ininv/970-l-r.html (accessed: 20.04.2019).

${ }^{29}$ UNCTAD. Transnational corporations. URL: https://unctad. org/en/docs/iteiit12v8n2_en.pdf (accessed: 20.04.2019).
}

TNCs starts to rise, the actual features of activities often differ from practice activities in the USA and Western Europe. Because of this major trend at the beginning of the $21^{\text {st }}$ century is the study of the theory and practice of TNCs in developing countries and countries with economies in transition. Brazil and Russia, as in our study, belong to such countries. To quantify the level of impact of TNCs on local businesses and the economy in general, we use the index of trans-nationalisation.

The transnationality index is mainly used for three types of TNCs:

Horizontally integrated - TNCs that produce identical or similar products

Vertically integrated - TNCs that combines the entire production chain in a GVC (from the purchase of raw materials to the sale of finished products)

Separate TNCs (diversified) - TNCs whose units are not connected by production, the units remain independent, while the headquarters performs the functions of a strategic regulator.

To properly understand the impact of TNCs on the economy, it should be noted that they can exist in the main organisational and legal forms: $\mathrm{U}$-forms, D-forms, $\mathrm{H}$-forms, $\mathrm{M}$-forms, and even X-forms. Each of these forms determines the degree of influence and subordination of the company's division relative to Central management. Currently, the most common form is D (from the word divisional) in 


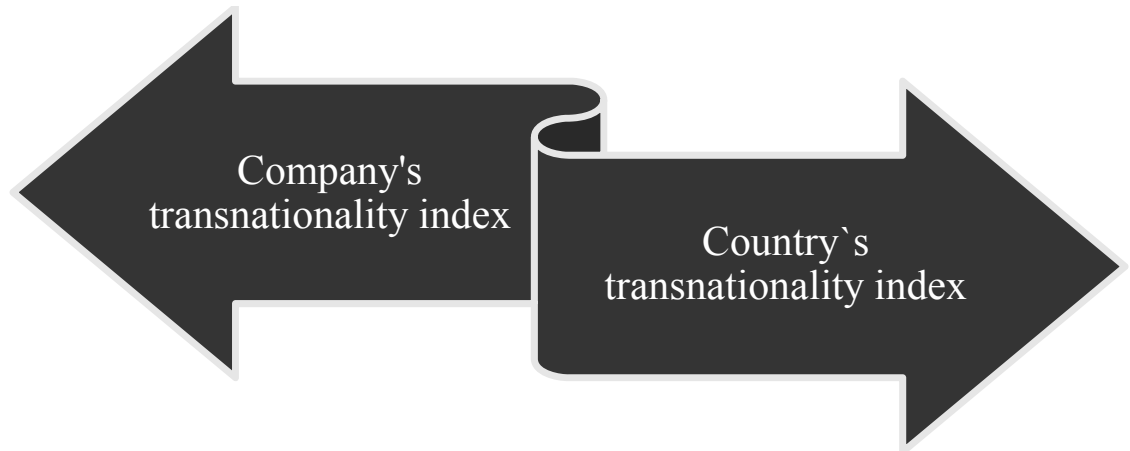

Fig. 12. Two main forms of the transnationalization index

Source: Compiled by the author.

which the value of the transnationality index will be the most significant.

If we speak about the trans-nationalisation index, we should note that it can exist in two main forms (Fig. 12).

The company's transnationality index shows the extent to which TNCs are involved in the production of products and services in a country other than the country of headquarters. As an example, the customs rules for determining the countries of origin of the goods, which determine what customs duties and quotas will be used in relation to the products depending on the country in which it was produced - this becomes relevant when the products go through many stages of processing in different countries. Suppose, for example, drug substances were purchased from Pakistan, mixed in China, packaged in Russia, but all the equipment is manufactured in Austria (blister card and plastic are Austrian, the tablet is Pakistani, and the substance is Chinese, but packaged in Russia). The question arises - what country of origin are the pills? Especially if these works were done under the contract with the Indian Pharmaceutical Corporation.

Of course, the basis for the countries themselves will be spelt out in the contract, but according to international rules, which are higher than the normative level of the contract between individual companies, the country of origin will be the country where more than 50 per cent of the added value of the product is produced. For regulation of these relations of TNCs in international trade, there is a FEACN - commodity nomenclature of foreign economic activity and Incoterms - determining the moment of transfer of risk liability and payments from one counterparty to another.

For determination of the Transnationality Index, it is necessary to know three indicators:
The ratio of the total value of property abroad to the total value of assets in the Corporation (the share of foreign assets)

The ratio of revenue received abroad to total revenue of TNCs (share of foreign sales)

The ratio of personnel abroad (in subsidiaries, branches, and representative offices) to the total number of employees in the corporation (the share of foreign personnel).

The general formula 4 for calculating the Transnationality Index of TNCs will be ${ }^{30}$ :

$$
\frac{\left(\frac{A f}{A t}+\frac{B f}{B t}+\frac{P f}{P t}\right)}{3}=\mathrm{TNI}
$$

where:

TNI - Transnationality Index of a company

$A f$ - foreign assets of TNC

At - total assets of TNC

$B f-$ foreign revenue of TNC

$B t$ - total revenue of TNC

$P f$ - foreign personnel of TNC

$P t-$ total number of employees of TNC.

The maximum value of this index can be 1 (100 per cent), the closer this indicator is to 1 , the more this company meets the characteristics of TNCs. Accordingly, the closer the index to 0 - the less the company meets the status of TNCs.

The Transnationality Index for given country characterises the level of influence of TNCs on the economy of the country or region in consideration. To calculate the trans-nationalisation of the country we need to know the following metrics: level of FDI and its share in the total investment of the country; the level of GDP of the country; the share of TNCs'

\footnotetext{
${ }^{30}$ Russian Foreign Trade Academy. Transnationality Index. URL: http://www.vavt.ru/glossecon/glossecon/LSPECDAC 8 (accessed: 20.04.2019).
} 
branches in the volume of production in natural and cost expression; the percentage of employment in TNCs of total employment in the country.

Therefore, the transnationality index of the country will be calculated as follows (Formula 5):

$$
\frac{\frac{F D I}{C}+\frac{F D I a}{G D P}+\frac{\mathrm{POb}}{\mathrm{TPOc}}+\frac{\mathrm{TEb}}{\mathrm{TEc}}}{4}=T N I,
$$

where:

TNI - Transnationality Index of the country

FDI - total FDI, $\mathrm{C}$ - the capital of the country

FDIa - FDI accumulated in the country

GDP - a Gross domestic product of the country

$\mathrm{POb}$ - production output in the branches of the corporation

TPOc - total production output in the country $\mathrm{TEb}$ - total number of employees in the branch

Tec - total number of employees in the country.

The closer this indicator is to 1, the higher the impact of TNCs on the country's economy; the closer this indicator is to 0 , the lower the level of influence of TNCs on the country's economy.

These indicators of the degree of trans-nationalisation are monitored by various international organisations, in particular, UNCTAD. According to the report on the activities of TNCs and global investments in 2018, the main trend of business trans-nationalisation is the increase in the political component and the growth of barriers to trade between countries. As a result, in 2017, FDI in the whole world decreased by $1 / 4$. First of all, it affected countries with economies in transition and underdeveloped markets. For prevention of this trend from developing in the future, it is a need for sustained growth in the activities of TNCs in emerging markets.

In the context of the $4^{\text {th }}$ industrial revolution, TNCs are beginning to actively purchase the scientific achievements of developing countries. It leads to the change of global value chains, and as a result, countries having higher value FDI and TNI become the new technological leader. A key issue for developing countries and countries with economies in transition is to overcome the structural constraints of infrastructure development and to enable the strategic and long-term trans-nationalisation of business. By regions of the world the main trends of trans-nationalisation are as follows:
The decline in global FDI by $\$ 1.43$ trillion is the main reason for the restriction of M\&A Processes by the European Commission and the US Antimonopoly service

FDI stagnation in developing countries - the value of FDI remains consistently low after the previous fall

The decline in FDI in underdeveloped countries in Africa is caused by natural and climatic problems: drought, agricultural decline

FDI to the most developed countries decreased by more than $1 / 3$ ( $700 \mathrm{bn}$ ) due to the decline in corporate restructuring activity, as well as negative expectations of investors about the change in the political situation in Europe (Brexit).

Consider the general dynamics of FDI by country group in Fig. 13.

From Figure 13, the following conclusions can be drawn:

1. Currently, there is the uncertainty of international investors in the field of geopolitics, which causes instability of investors' expectations from the world economy.

2. Forecasts of dynamics for 2019-2020 show relative instability due to further uncertainty about the dynamics of prices for natural resources (oil, gas, coal, gold), which may have been caused by a decrease in the credit ratings of the main importers of these resources (Middle East, Russia), as a result, even in a positive scenario, the dynamics of investments will still remain below the global average over the past 10 years.

3. Reducing the role of GCV in global investment dynamics due to tax and customs reforms in the EU and the US.

4. The decrease in return on investment - in recent years it has decreased from 8.1 per cent to 6.7 per cent annually, and the decline is observed in all regions of the world. It may affect long-term FDI in the world.

5. Such processes affect the primary sector of the economy, services, and manufacturing, which account for more than three-quarters of the world's GDP. Herewith, for underdeveloped countries, FDI is, in fact, the only source of survival, as it provides more than half of the GVC in the regions.

Gradually, one can see the shift of the GVC from material forms to intellectual and information forms, which in the works of domestic and foreign scientists is defined as "digital economy" and "digital technologies in the economy”. The existing system 


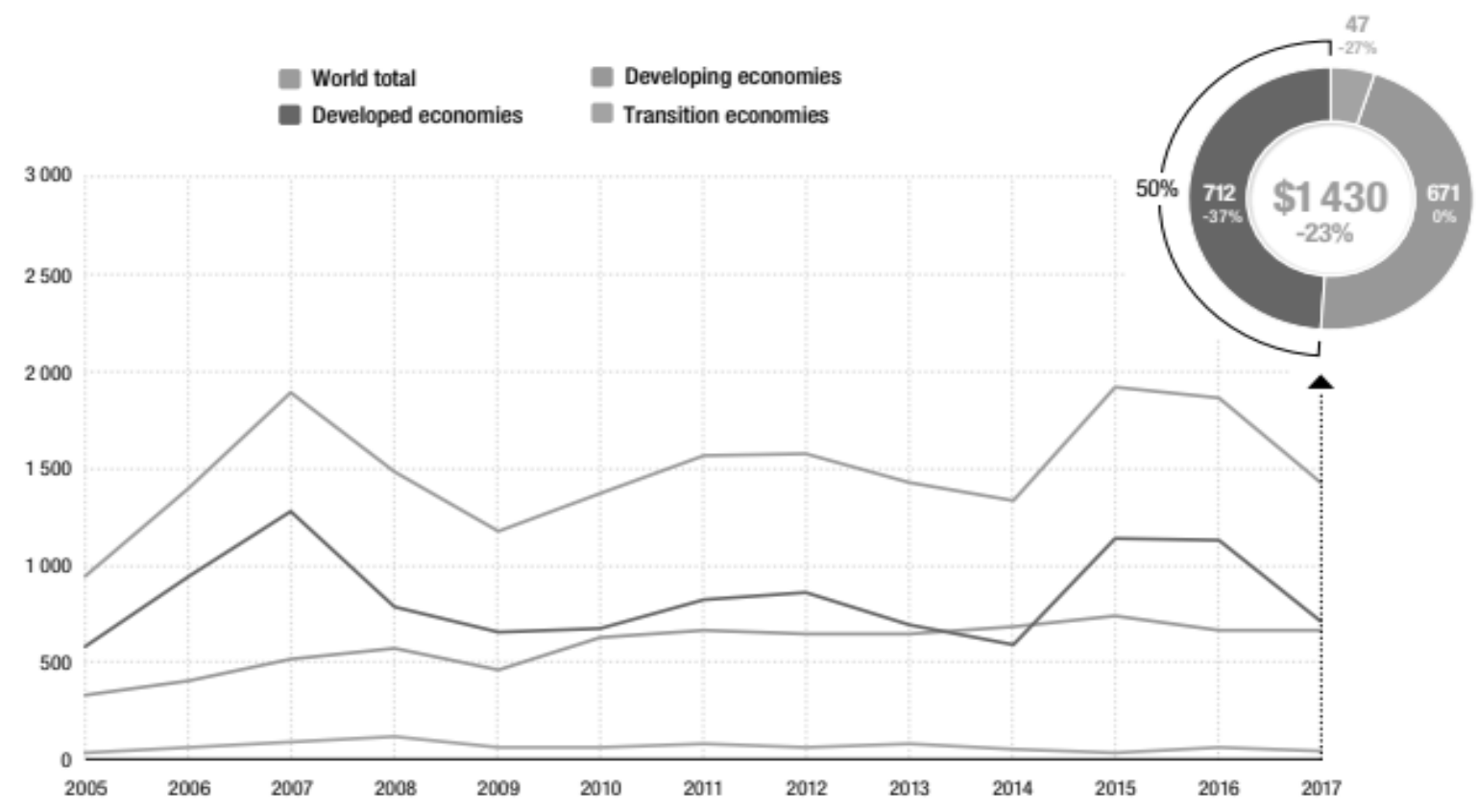

Fig. 13. FDI inflows, global and by a group of economies, 2005-2017 (Billions of dollars)

Source: UNCTAD, FDI/MNE database. URL: www.unctad.org/fdistatistics (accessed: 20.04.2019).

of world economy shows that about hundreds of the world-leading TNCs included in such ratings as S\&P 500, FTSE 100, Fortune Global 500, Dow Jones define the culture and processes in the world economy. That is, they provide most of the added value in the field of GVC.

Let us consider in more detail the level of transnationalisation of countries and regions, which we present in Fig. 14.

As you can see from this figure, the negative FDI dynamics shows a negative trend in almost all countries and regions, and it is logical that the largest investor and recipient of FDI in the US and Chinese economies. France, Germany, Indonesia show the positive dynamics and the CIS countries, including Russia, are in the negative trend, as well as almost all countries of Southern and Eastern Europe, which are more affected by the global financial crisis began in 2012. It is characteristic that most of the recipients of FDI are the developing countries and developed countries are among the larger investors.

On average, the return on investment is growing after the decline in the level of development of the country, and this is understandable. In business, there is a practice called "risk-free" whereby investments in riskier assets are offset by higher returns (taking into account discounting and the accumulated future value of the annuity). For example, deposits in banks that are lower-rated promise higher returns than investing in risk-free government bonds. In this regard, for developing countries, we can recommend the search for new sources of financing, namely portfolio investment, long-term loans, short-term credit, subsidies, debt refinancing and so on.

At present, the structure of financial flows from the three types of countries under consideration can be described as follows: for developing countries and countries with economies in transition take about 40 per cent of the GVC, underdeveloped countries - about 15-20 per cent of the GVC, and developed countries account for 35-40 per cent of the GVC. In this regard, we see a prospective investment in real production and the real economy, which should increase international trade operations and their profitability.

Further, we will consider in more detail the economies of Russia and Brazil, as for Brazil, the participation rate in GVC as a percentage of exports is about 41 per cent (Latin American countries), and for Russia more than 50 per cent as for a country with an economy in transition, while the average growth rate of participation in the GVC of these countries and regions that they represent is on average higher than in developed countries.

Despite the development of science and technology peak of which occurred at the beginning of the $20^{\text {th }}$ century (conveyor, the basis of nuclear technology, breakthroughs in pharmaceuticals, electric car), they were used to a large extent for military purposes. As a result, there was skew and a decrease in the stability of the global production system. Two 


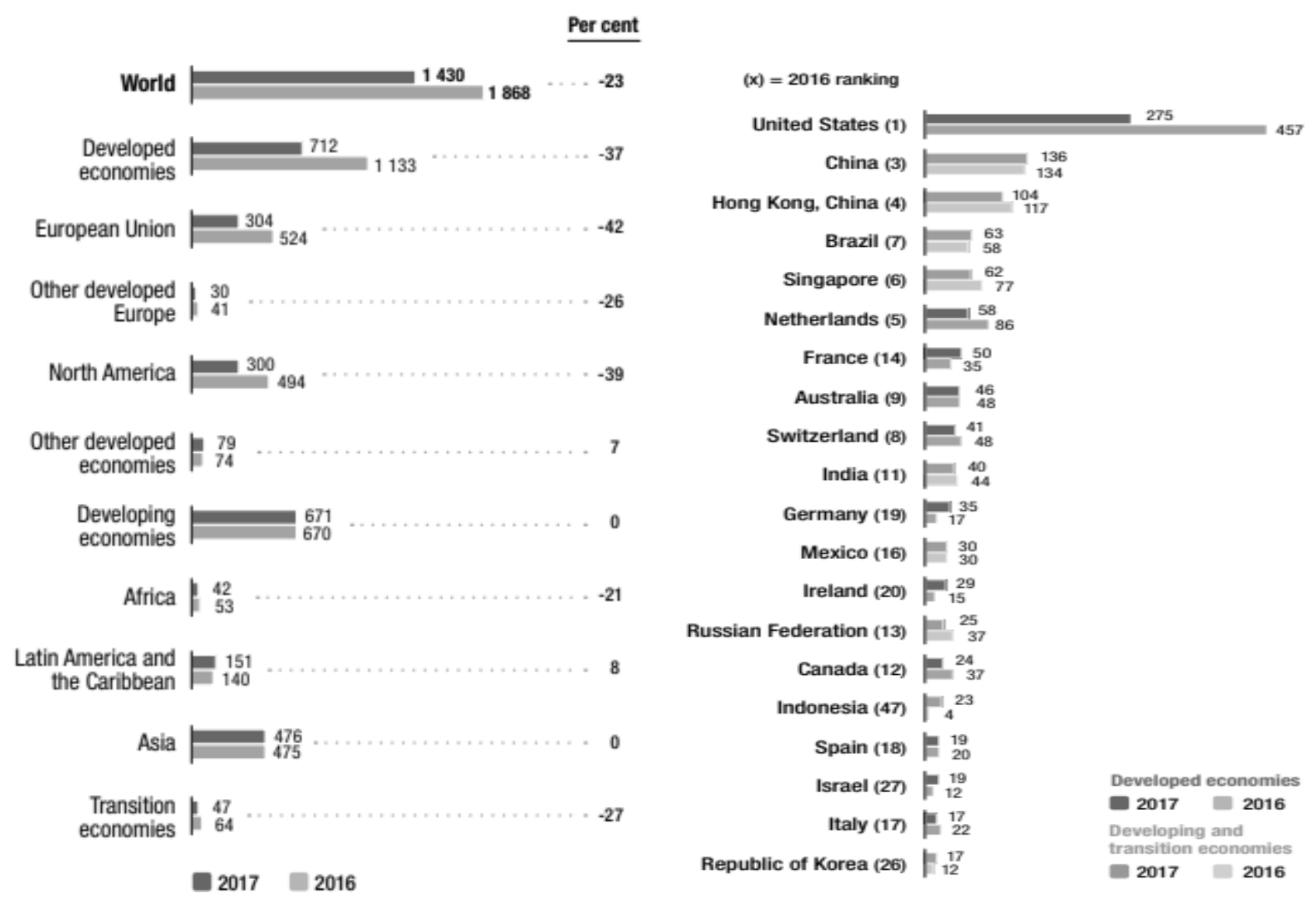

Fig. 14. FDI inflows, by region and top 20 host economies, 2016-2017, (Billions of dollars)

Source: UNCTAD, FDI/MNE database. URL: www.unctad.org/fdistatistics (accessed: 20.04.2019).

world wars led to the almost complete annihilation of production areas and production capacities of the warring countries (industry of Japan, Germany were almost destroyed). This led to a decrease in the global population and a decrease in migration due to the closure of the territory (the Berlin wall).

Paradoxically, the almost complete destruction of production was at the same time the push for further development. The most striking example is the Japanese "economic miracle" and the development of the economies of the "Asian tigers" (Singapore, Malaysia, Hong Kong), whose industry and economy were recreated from scratch, with special attention paid to the service sector, which according to most investors is the engine of further economic development (first, production should be created, and on its basis should develop related services - this point is the most sustainable in the world economy).

In this context, I would like to note the current trends in Russia - the increasing role of the digital economy and digital marketing in the activities of TNCs. However, contrary to the popular opinion of many modern authors, the digital economy cannot and should not be a central element of sustainable development of the Corporation, it is rather appropriate to talk about digital technologies in TNC technology, because otherwise if it is now digital in view of the development of IT technologies, it should have been "electric economy", "steam economy" and so on in the past. But we know perfectly well that there were no such economies. Therefore the activities of the Corporation should be considered from the standpoint of their real assets, since in the opposite point of view "removing the plug from the outlet" should actually stop the whole process of development, however, corporations that "bake bread will continue to bake bread", and those that "sew panties will continue to sew panties".

The more complicated is the situation with digital marketing. Often considered the BRICS countries, the investment attractiveness of the territory for TNCs is considered exclusively from advertising positions, that is, replacing the real production economic conditions with propaganda. Even analysing the sites of investment agencies of the territory - leaders in terms of investment attractiveness (in Russia - it is Moscow and the 


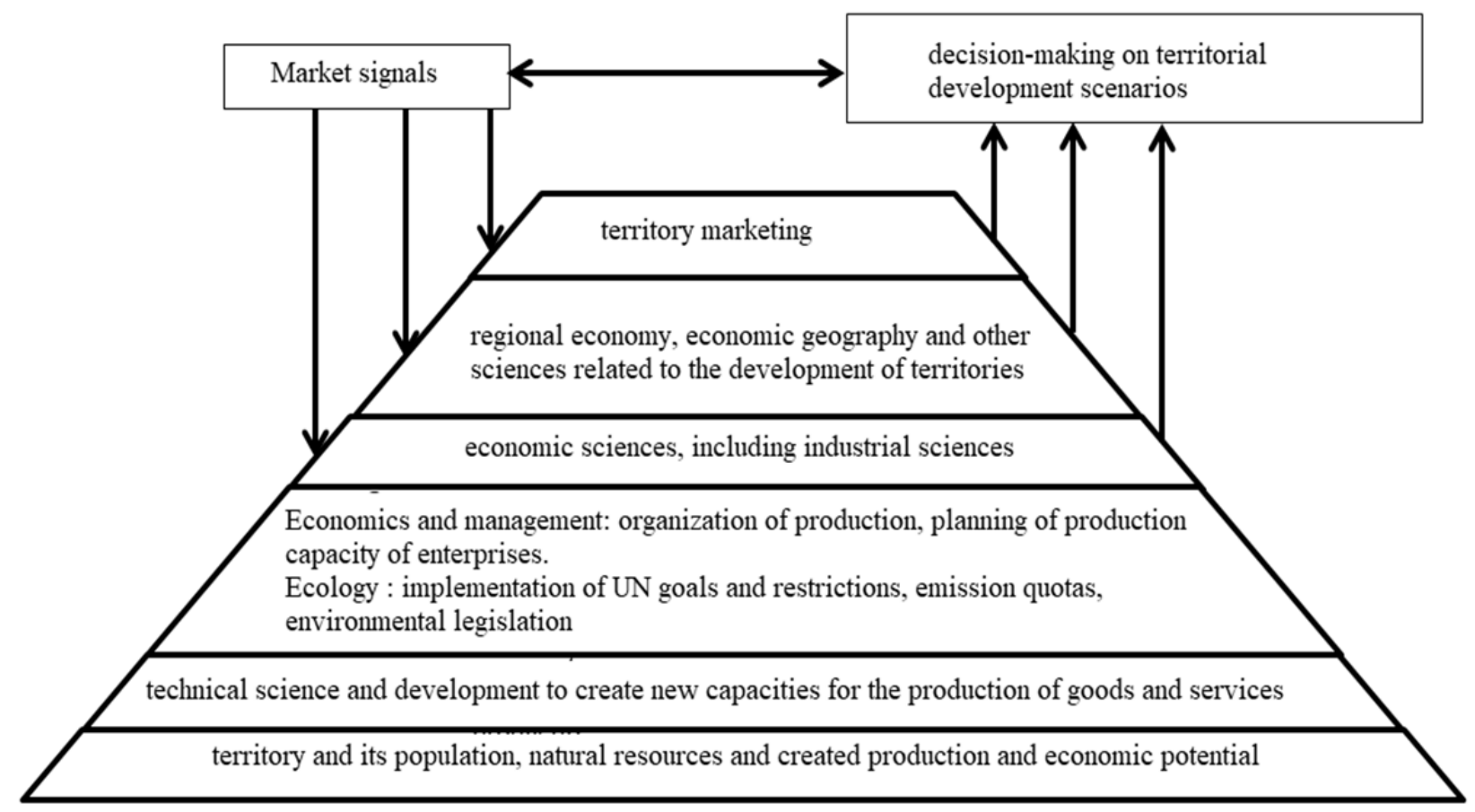

Fig. 15. Place of marketing territories in the General system of Sciences

Source: Compiled by the author.

Republic of Tatarstan), among the indicators characterising the territory there is no production! The length of roads and the share of water resources are clearly not related to them, so we decided to clarify this situation; marketing, advertising (digital marketing) are actually "cherry on the cake", while competent investors choose the territory where they will have their production facilities (Fig. 15).

As follows from the figure, when the evaluation of the performance of TNCs in the countries it is necessary to show first of all how they have affected the real level of living of the population in the country (real social efficiency); how they have developed small business and innovative entrepreneurship in the country (economic efficiency); how they were able to increase the flow of funds in the state budget (budget efficiency). That is, regardless of the topic of the graduate qualification work, the impact of TNCs on the economy and society should be real, not digital (virtual), and this is the main indicator of the quality of the work performed.

\section{Conclusions}

1. The role of TNCs in global value chains (GVCs) is considered. TNCs more effectively spend the available factors of production, forming ascending and descending connections from the creation to the sale of goods, forming part of its value-added. The defining role of TNCs in the globalisation processes of the twentieth century, which are still taking place, but now in developing countries and countries with economies in transition, has been identified.

2. The key approaches to the concept of "transnational corporation" are studied: production, financial, legal. For the purposes of this work the conclusion is made about the use of the classical definition of the UN, according to which TNCs should operate in 2 or more countries, to implement the general policy and strategy of development of the group (e.g. holding), but also have an organisational and administrative, legal and financial-economic impact on downstream business units.

3 . The differences between the concepts of "transnational corporation" and "corporation" are characterised. TNC is a corporation, but not every corporation is a TNC, that is, TNC is a narrower concept. If the corporation is localised in one country and carries out the detail in other countries (including branches, representation, dependent subsidiary companies) in that case, the corporation can be classified as transnational.

4. A schematic diagram of the TNCs development in the country in terms of a systematic approach has been developed. TNCs are an open system, influenced by many stakeholders, forming the institutional, organisational, economic basis of TNCs' work in the country. At the same time, the development of TNCs determines the 
development of the surrounding meso- and macroenvironment and depends on it; that is, this process is bi-directional.

5. The differences between the concepts of "transnational corporation" and “multinational corporation" are revealed, namely, that TNCs do not have a centralised management system within a divisional structure (headquarters is responsible for the policy and overall strategy of the subsidiaries and affiliates group); TNCs are not involved in subsidiary relations, but own assets around the world; TNCs are more focused on the socio-environmental and economic interests of local markets and the local community, they are more flexible in terms of linking goals and maintaining their interests (if necessary, it is possible to change the country of localisation).

6. The synergistic effect of the activities of TNCs is analysed. As a result of combining assets and business units under a single management, firstly, the efficiency of work increases, and secondly, the value of the group of companies increases. The peculiarity of these processes is that the total efficiency and cost of business units is more than a simple arithmetic sum when considering the indicators of their work separately.

7. The key socio-economic and institutional performance indicators of developed, developing, and transition economies are considered. The difference in the standard of living, the economy and the business environment in these countries are clearly shown. It is shown by what criteria the UN, the International Monetary Fund and the World Bank classify countries into the above categories.
It is shown that Russia and Brazil belong to the category of developing countries.

8. The dependence of TNCs development in an integrated life cycle approach, sustainability, and risk activities is shown. It is clearly demonstrated that in fact, both countries and TNCs are essentially "black boxes" of the economy at the entrance, which has raw materials, and at the exit, which has finished products. Due to the fact, that the systems under consideration are fundamentally open, their mandatory element is the accounting of market signals to the input and output flows, as well as the construction of the inverse relationship circuit with subsequent corrective action. As a result a revolutionary (abrupt growth), that is, a sharp (instant) transition to a new level of development is fundamentally impossible without a critical accumulation of innovation and qualification level in each of the systems, and not only in one of them.

9. The analysis of the economic policy of Russia and Brazil is carried out. It can be concluded that the serious impact of the global financial and economic crisis on the economies of the countries in question, GDP, foreign trade turnover, inflation, unemployment have deteriorated, which increases the role of TNCs as engines of economic development in overcoming these crisis phenomena.

10. The key problems of the activities of Russian and Brazilian TNCs themselves are identified: high level of corruption and transparency, low level of investment in innovative development, insufficient influence on the international markets situation, loss in the TNCs competitiveness from leading developed countries.

\section{References}

Catmull, E., \& Wallace, E. (2016). Corporation of geniuses: How to manage a team of creative people. Moscow: Alpina Publisher.

Contemporary international relations. 2nd ed. K.V. Belozerov et al. (Eds.). Moscow: Yurayt Publishing house, 2019.

Dunning, John. (1979). Toward an Eclectic Theory of International Production: Some Empirical Tests. Journal of International Business Studies, 11(1), 9-31.

Fomina, O. N. (2016). The legal status of a business corporation in the USA and joint-stock company in the Russian Federation. Comparative legal analysis. Moscow: STATUTE.

Glosecki A. (2017). Open and closed corporations. The features of turnover share in the charter capital of limited liability companies: Legal and economic aspects. Moscow: STATUTE.

Gorbatkow S.A. et al. (2018). Neural network and fuzzy simulation methods for diagnostics and prediction of bankruptcies of corporations: Monograph. S.A. Gorbatkov (Ed.). Moscow: Publishing House "Prometey".

Grechko, E. A. (2019). Geographical differences in corporate governance systems: Studies. 2nd ed. Moscow: Yurayt Publishing House.

Krasnostanova M.V. (2014). From the inventive team to the high-tech corporation: the human factor and the dynamics of the innovative project: Textbook. Moscow: Faculty of Economics, Lomonosov Moscow State University. 
Kukushkina Yu. M. (2016). Global value chains and corporate interests of transnational corporations. Journal of Modern competition, 2(56), 107-117.

Kuznetsova, G. V., \& Podbirala, G. V. (2019). International trade in goods and services. In 2 parts. 2nd ed. Moscow: Yurayt Publishing House.

Leikin, Dmitry. (2017). Key issues of group management. Moscow: Alpina Publisher.

Miloslavskaya, M. M. (2014). Aspects of improving the management system of diversified corporations: Monograph. Moscow: Scientific consultant.

Muravyov, A. V. (2014). Transnational corporations: Textbook. Moscow: MSTU.

Petrova, G. V. (2019). International financial law. Moscow: Yurayt Publishing House.

Ponomareva, T.N. (2014). The legal status of a commercial organisation as a corporation: Textbook. Vologda: Vogtu.

Regional economy and spatial development. (2017). In 2 volumes. 2nd ed. L.E. Limonov, ed. Moscow: Yurayt Publishing House.

Romachkin, T. V. (2016). Formation and development of TNCs in the context of globalisation. Saratov: Publishing Center "Science".

Shimko, P. D. (2019). The world economy and international economic relations. I.A. Maksimtsev (ed.). Moscow: Yurayt Publishing House.

Shimko, P. D, \& Shimko, D. P. (2018). Economics of transnational companies: textbook and workshop for undergraduate and graduate. 2nd ed. Moscow: Yurayt Publishing House.

Stragis, Yu.P. History of Economics. In 2 parts. 2nd ed. Moscow: Yurayt Publishing House, 2019.

Tekutiev, D. I. (2017). The legal mechanism of increase of efficiency of activity of members of the management bodies of the corporation: Monograph. Moscow: STATUTE.

The capital structure of corporations: theory and practice: Monograph. I.V. Nikitochkina, S. G. Makarova (Eds.). Moscow: Faculty of Economics, Lomonosov Moscow State University 2014.

Vernon, Raymond. (1966). International Investment and International Trade in the Product Cycle. Quarterly Journal of Economics, 80(2), 190-207.

The world economy and international economic relations. (2019). A.I. Pogorletskii, S.F. Sutyrin, eds. Moscow: Yurayt Publishing House.

Zubenko, V. V., Ignatova, O. V., Orlova, N. L., Zubenko, V. A. (2019). The world economy and international economic relations. Moscow: Yurayt Publishing House.

Анализ влияния THК на экономику развивающихся стран и стран с переходной экономикой

Фарида Джорубова

BA in Economics, Международный финансовый факультет, Департамент мировой экономики и мировых финансов, Финансовый университет, Москва, Россия

Аннотация. Формирование и экспансия ТНК, особенно в развивающихся странах и странах с переходной экономикой, обусловлены, прежде всего, сложной сетью международных производств и локализацией деятельности на перспективных рынках за счет прямых иностранных инвестиций (ПИИ). Эти процессы с каждым годом все больше становятся одной из ключевых составляющих мировой экономики. Задачами настоящей работы являются описание сущности и содержания понятия «транснациональная корпорация», выявление ключевых факторов и характеристик современного транснационального бизнеса в развивающихся странах и странах с переходной экономикой, а также рассмотрение места и роли ТНК в названных странах. Ключевые слова:ТНК; ПИИ; глобализация; БРИКС 